\title{
Consumers' food cycle and household waste. When behaviors matter
}

\author{
Marco Setti ${ }^{a^{*}}$, Federico Banchelli ${ }^{a}$, Luca Falasconi ${ }^{a}$, Andrea Segrè ${ }^{a}$, Matteo Vittuari ${ }^{a}$
}

\author{
a Alma Mater Studiorum - University of Bologna, Department of Agricultural and Food Sciences \\ Viale Fanin 50, Bologna 40127 (I) \\ ${ }^{*}$ Corresponding author. \\ E-mail address: marco.setti@unibo.it
}

Amount of words: 8,668

\section{Highlights}

- Household food waste warrants the analysis of the whole consumer's food cycle.

- The more upstream is the phase the stronger is the influence on household waste.

- The gap between purchasing and outcome leads to additional uncertainty.

- Individuals resort to heuristics and deviate from the standard economic model.

- Situational factors (food retail) influence food waste generation in homes.

Abstract: Recent studies have shown that consumers encounter various conflicting motivations that influence the prevention of household food waste. Food choices are rooted in deep-seated judgments, such as emotions, habits, and values, thus raising the cognitive dissonance between motivation and behavior (intention-behavior gap). The complexity of this subject increases when considering that food waste is driven by repetitive, multiple, and hidden individual choices and influenced by a composite set of situational factors. This study argues the presence of a critical distance between food choices and waste generation in homes and this factual interval (behavioroutcome gap) further affects consumer's decision-making when comparing available options. Employing data from a three-year survey of a national representative panel of Italian consumers, this study develops a system of regression models using path analysis methodology. The objective is to measure the relationships between the different phases of the food consumption cycle and rank their contribution to waste. The results suggest that the more upstream the phase, the stronger the influence on food waste generation in homes. Purchasing emerges as the most critical choice of the consumers' food waste cycle. This gap between behavior and outcome adds uncertainty to food decisions, which reverberates on behavioral beliefs and as a result, leads consumers to resort to heuristics. The findings allow for the identification of a set of behavioral patterns with implications on food waste generation. Furthermore, purchasing decisions are exposed to out-of-home contextual factors, suggesting that food retail can affect consumer behaviors relevant to household food waste.

\section{Keywords}

Consumer; attitude; behavior; food waste; purchasing; food retail. 


\section{Introduction}

Why do individuals make and repeat choices that reduce their utility and lead to negative environmental and social impacts? What are the key behavioral factors explaining these apparently irrational actions? These questions assume a high complexity in the context of household food waste.

While at the global level, one-third of food production is wasted or lost along the entire food chain (FAO, 2011), in industrialized nations, the largest share of waste is concentrated at the household level (Griffin et al., 2009; Parfitt et al., 2010; Gustavsson et al., 2011; Gunders, 2012). In the EU-28, it amounts to $46 \%$ of total and $173 \mathrm{~kg}$ food wasted per person each year (Stenmarck et al., 2016). In the United Kingdom, more specifically, food waste represents an average annual cost of $£ 680$ in household budget (WRAP, 2011).

The magnitude and pervasiveness of household food waste suggest a number of implications. On the one hand, analyses of consumers' food choices (e.g., contingent valuation surveys) should consider the realm of food waste and the implications on their payoff. On the other hand, the drivers of food waste should include not only socioeconomic conditions (Andreasen, 2002; Vermeir and Verbeke, 2006; Evans, 2012, 2011; Farr-Wharton et al., 2014; Setti et al., 2016), but also individual motivations and behaviors pertaining to the general food domain. In fact, when consumers deal with various food resources, their evaluations tend to include a series of volitional factors such as food security, status concerns, time pressure, and food waste. Moreover, food decisions are influenced by deep-rooted and repeated judgments such as emotions, hunger, values, and habits (i.e., "visceral factors"; Lowenstein, 1996; Verplanken et al., 1998; GrahamRowe et al., 2014). Thus, a high uncertainty level tends to characterize consumers' food choices.

These conscious and unconscious behavioral precursors indicate that the performed food behavior can generate an array of outcomes in terms of their intrinsic characteristics, subjective relevance, and moment of perceived attainment. This leads consumers to face a set of personal motivations-for each food behavior-that either compete or cohere with the intention to prevent or reduce food waste. In this assortment, food waste-related motivation can show a cognitive dissonance (Festinger et al., 1956) with the relevant food choices causing an intention-behavior gap (Graham-Rowe et al., 2015). This study argues that a separation between food choices and expected consequence (food waste), that is a behavior-outcome gap, can further influence consumers' decision-making and the achievement of the goal.

Indeed, while in the broader waste domain, the separation between action and delayed impact is relatively well-assessed, household food waste is the result of repetitive, multiple, interactive, and sequential food behaviors (i.e., purchasing, storing, and portioning; Quested et al., 2013) that are not fully covered by existing research. Although the various phases of the consumers' food cycle have been taken into consideration, and surveys reveal heterogeneities among different contexts, limited evidence shows major influences of the involved food decisions on household waste generation. This highlights the need for a systemic approach to analyze the behavioral process as a whole. Thus, this study attempts to answer the following research question: which consumer food behavior is crucial in terms of consequences on the generation of household food waste? The envisaged delay with which this food behavioral effect is perceived or experienced is expected to entail a series of implications at both the individual and situational level.

As for the consumer, a behavior-outcome gap can deliver an additional degree of uncertainty to food decisions. Considering the behaviors related to food and food waste are private and, thus, in essence not visible, the inherent risks cannot be limited by simply learning from others' experiences. This additional source of uncertainty raises the need for new research on the main non-standard behavioral schemes that can influence the generation of household food waste and, consequently, cause consumers to experience reduced private (and public) benefit or moral 
concern. Moreover, the expected deviation from rational and reasoned choices can influence consumer's overall decision-making with possible repercussions on its earlier precursors (i.e., beliefs). This, in turn, can amplify the trade-offs between individuals' motivations when they compare available food options, triggering a feedback loop that further raises the level of uncertainty.

At the situational level, the identification of food behavior(s) with a higher impact on household food waste, and their pivotal predictors suggest more precise and effective preventive interventions. Adopting data from a three-year survey of a statistically representative panel of Italian consumers, this study develops a system of regression models using path analysis methodology with three key research objectives. It aims to (i) rank food behaviors in their effect on the generation of household food waste, (ii) deduce the most affected and, thus, critical food behavioral precursor, and (iii) identify possible behavioral patterns consumers can adopt to react to uncertainty. Thus, this study compares the influence of the single phases of a food consumption cycle on household waste and then, analyzes the interactions among them. By identifying crucial consumer decisions and their decisive antecedent, this research intends to contribute to a better understanding of food waste-related behaviors and provide theoretical and operational insights on possible strategies to prevent and reduce household food waste.

\section{Theoretical background}

A well-established behavioral theory that contributes to the understanding of human behaviors is the Theory of Planned Behavior (TPB) (Ajzen, 1991, 2015). This socio-psychological construct provides a general description of an individual's decision-making by identifying the determinants of (food) behavior. With the objective of explaining individual behaviors and their predictors, TPB is being adopted with success in different research fields-from environmental psychology (Thøgersen, 2014; Russell et al., 2017; Schluter et al., 2017) to contingent valuation (Borger and Hattam, 2017) and innovation diffusion (Kiesling et al., 2012)—and particularly, a growing number of studies focused on household food waste.

Even if "TPB doesn't assume rationality on the part of the decision maker" (Ajzen, 2015, p. 126), the proposed framework largely refers to the cognitive antecedents of behavior. Beliefs (considerations) are the earliest behavioral precursors TPB recognizes in individuals' decisionmaking process. It distinguishes three types of beliefs (behavioral, normative, and control) determined by the subjective perception of a specific factor (strength of belief) and a subjective evaluation. As for behavioral beliefs, which are central to this study's objectives, TPB identifies the former with the discerned consequences resulting from an action ("the subjective probability that behavior produces the outcome in question", Ajzen, 2015, p. 127). Coherently, the latter is concerned with the normative value of behavioral outcome ${ }^{1}$. The (perceived and evaluated) relationship between behavior and its specific effect form the behavioral belief in its dual dimension (awareness and knowledge).

In general, the literature on food waste deals with the integration of TPB's beliefs with noncognitive determinants such as moral norms (Graham-Rowe et al., 2015; Stancu et al., 2016; Mondéjar-Jiménez et al., 2016; Diaz-Ruiz et al., 2018), habits (Visschers et al., 2016), and emotions (Russell et al., 2017). This study, in perspective, analyzes the performance of each food behavior by measuring the impact on household waste generation to elicit the implications for the two components of the behavioral beliefs.

Along the process of human decision-making, TPB enrolls behavioral beliefs as the immediate

\footnotetext{
${ }^{1}$ With reference to normative value, Stern et al. (1999) underline the primordial characteristic of the precursor that implies low adaptability to changes and capacity to explain behavioral performance.
} 
antecedents of attitudes toward behavior and its outcomes. ${ }^{2}$ According to the sign of the behavioral belief (i.e., subjective evaluation of outcome), attitude expresses positive or aversive thoughts and feelings about behavioral performance (Graham-Rowe et al., 2015; Russell et al., 2017). While in the more general context of food consumption, an individual's attitude can be a relevant predictor of the decision (Ajzen, 2015), findings on household food waste show a high degree of variability. On the one hand, numerous studies have clearly highlighted unfavorable attitudes toward behaviors associated with food waste (outcome), often in terms of guilt (Brook Lyndhurst, 2007; Evans, 2012; Quested et al., 2013; Graham-Rowe et al., 2014, 2015; Parizeau et al., 2015; Stancu et al., 2016). On the other hand, attitude is considered a minor predictor of behaviors generating food waste (Vermeir and Verbeke, 2006; Evans, 2012; Watson and Meah, 2013; Farr-Wharton et al., 2014; Russell et al., 2017; Hebrok and Boks, 2017).

Despite the weak role attitude plays in predicting a specific behavior when food waste is the evaluated consequence, in the TPB framework, an individual's attitude is assumed to be the precursor of personal motivation (intention). Because each food behavior is typically associated with various outcomes, a cluster of motivations influences consumers' decisions. In particular, the motivation related to food waste can demonstrate a series of relationships with alternative and complementary intentions to carry out a certain food behavior. The literature suggests food security as a major conflicting intention that diverges consumers' attention from food waste reduction to alternative goals. Indeed, food security is not strictly limited to the individual sphere (selfgratification), but involves the desire to avoid the lack of food availability for family or guests (i.e., risk aversion and status concerns) (Evans, 2012, 2011; Graham-Rowe et al., 2014; Neff et al., 2015; Visschers et al. 2016). Time constraints or pressure are additional reasons that causing consumers (e.g., the youth; WRAP, 2014) to not consider food waste prevention among their priorities. Moreover, some authors find that food safety (i.e., risk aversion and personal preferences) can drive individuals to the adoption of rigid criteria in the assessment of food quality and thus, discard edible food (Kriflik and Yeatman, 2005; Watson and Meah, 2013; WRAP, 2014; Neff et al., 2015; Canali et al., 2017).

By contrast, some other studies suggest that the motivations to reduce food waste are mainly supported by moral and ethical reasons (Evans, 2012; Gjerres and Gaiani, 2013; Stefan et al., 2013; Graham-Rowe et al., 2015, 2014; Parizeau et al., 2015), whereas environmental concerns do not appear particularly relevant (Watson and Meah, 2013; Quested et al., 2013; Graham-Rowe et al., 2014). Given the growing attention paid to food quality and practices, health considerations represent another factor that can positively stimulate food waste reduction (Quested et al., 2013; WRAP, 2014; Parizeau et al., 2015).

As for economic concerns, recent findings reveal the ambiguity of related motivational patterns. Price variability and income constraints can not only induce consumers to reduce household food waste (Quested et al., 2013; Graham-Rowe et al., 2014; Stancu et al., 2016), but also stimulate over-purchases of discounted, lower-quality foodstuffs that lead to increased frequencies of in-home waste (Setti et al., 2016). While from the perspective of TPB, motivations are the antecedent denoting a specific behavior, in food-related decision-making, the heterogeneity of motivations implies, by design, possible inconsistencies with the behavior (cognitive gap). In addition, when considering household food waste, certain moderators might contribute to the misalignment between intention and behavior, such as habits (Graham-Rowe et al., 2015) and perceived behavioral control (Ajzen, 2015). Furthermore, a series of consumers' food behaviors may be held accountable for the growing disposal of foodstuffs; however, owing to local and individual diversity, there is no unanimity in literature on the most impactful decisions.

Surveys show that consumers' planning and shopping routines significantly affect the

\footnotetext{
${ }^{2}$ Instead, normative and control beliefs are the cognitive antecedents of subjective norms and perceived behavioral control (Ajzen, 2015).
} 
generation of household food waste (Brook Lyndhurst, 2007; Evans, 2012; Stefan et al., 2013; Stancu et al., 2016; Mondéjar-Jiménez et al., 2016; Ponis et al., 2017). To this effect, certain studies find that storage knowledge and procedures are the most influencing factors (Farr-Wharton et al., 2014; Graham-Rowe et al., 2014; Parizeau et al., 2015; van Holsteijn and Kemna, 2018), whereas when not directly linked, trained stockpiling practices are considered to play a strong preventive role (Visschers et al., 2016). Attention toward food preparation habits (Parizeau et al., 2015) and adoption of appropriate cooking procedures (Evans, 2011; WRAP, 2014; Graham-Rowe et al., 2014; Stancu et al., 2016) are broadly recognized as effective interventions to reduce waste generation, whereas leftovers are variably classified as either a major (Ventour, 2008; van der Horst, 2012; Ponis et al., 2017) or minor factor of domestic food wastage (Farr-Wharton et al., 2014).

The envisaged distance between food-related decisions and food waste generation (behavioroutcome gap) can cause an additional degree of consumer uncertainty. In a similar conclusion, this condition would reverberate on the antecedent behavioral beliefs causing a feedback loop (Ajzen, 2015). Understanding this presumed circumstance requires the analysis of individual's possible responses to uncertainty. When dealing with uncertainty, individuals resort to heuristics and adopt non-standard behavioral patterns (e.g., time-inconsistent decisions, excess diversification, dependence on decision framing) that deviate from TPB's assumption of rational and reasoned choices and the economic core (standard) model (DellaVigna, 2009).

\section{Methodology}

\subsection{Sampling and data management}

This research analyzes data on the food choices of a nationally representative sample of Italian consumers by region, age, and gender. Data are collected through annual computer-aided web interviews (the Waste Watcher Observatory) conducted during 2013-2015 (i.e., 1,706, 1,518, and 1,502 respondents, respectively) ${ }^{3}$. The first group of response or dependent (categorical dichotomous) variables identifies the individual role of the phases of consumers' choice cycle (i.e., planning/purchasing, storing, preparing, and eating) in driving household food waste. These four "phase variables" are measured in relation to food behaviors influencing waste generation (respondent selection of at least one item confirms the role of a given phase).

The planning/purchasing phase variable as a driver of household food waste is defined using a five-item scale, including incorrect appraisal of food needs and preferences, perception of food insecurity, over-purchase, and weekly shopping. The storing phase variable relates to a four-item scale covering food perishability and expired, moldy, or bad-tasting food. The preparing and eating phase variables are assessed on a one-item scale comprising of over-cooking and plate-leftovers. Next, two sets of explanatory variables are then selected. On the one hand, proximal factors (directly linked to food use) describing consumers' specific food routines and behaviors are associated with each related phase. On the other hand, distal factors depicting socioeconomic conditions that can influence consumers along the entire food choice cycle are included in the dataset (see tables 6-7 in the Appendix).

To compare and analyze the contribution of each phase of the consumers' choice cycle to the food waste generation, this research focuses on a second group of response variables. The frequency of household discarded edibles measures the self-reported monthly occurrence of

\footnotetext{
${ }^{3}$ Italy, where consumers are the main responsible for food waste, shows a high level of socioeconomic and cultural heterogeneity among areas, which offers to this study the opportunity to analyze a spectrum of consumers' food behaviors. Additional details on sources of items and data collection process are described in the Appendix.
} 
individuals' food waste behavior on an ordinal scale (i.e., never, sometimes, or often). To account for heterogeneity in consumer behaviors when dealing with variety in food resources, the comparative analysis is extended to six product categories-fresh bread, cheese, fruits and vegetables, milk and yoghurt, cold cuts, and eggs-which are selected in relevance to the observed frequency of food waste.

\subsubsection{Limitations}

Two key issues limit this study's results. Firstly, the gathered variables may be subject to an underestimation. This cognitive bias can be attributed to the formal participation in a survey using computer-assisted web interviewing and the self-assessed measures of food waste drivers and frequency (Ventour, 2008; Parizeau et al., 2015). Despite this limitation, the use of a survey is considered appropriate because the work does not aim at food waste quantification and compared to other methodologies (i.e., food waste diaries), it induces a smaller bias on consumers' food waste behaviors and reports finding as though they are not observed or judged by researchers.

Secondly, the adopted data management process assigns heterogeneous sets of constitutive items to the adopted phase variables and, in particular, a higher number to the planning/purchasing and storing stages. However, this can imply an underestimation of the role of the other phases (i.e., preparing and eating) in stimulating the generation of household food waste. Nevertheless, it should be emphasized that the choice of at least one item is assumed to be sufficient to consider the related phase relevant. Moreover, this does not hinder the storing phase from having the weakest influence on the waste frequency, while food-preparing activities remain a significant determinant of household waste.

\subsection{Methodological approach}

A system of regression models is implemented according to the path analysis methodology (Wright, 1934; Mueller, 1996) for the three cumulated years and following a two-step approach.

Firstly, a set of logistic models is developed to identify the main drivers of the single phases of the consumer's food choice cycle that contribute to food waste generation (Hosmer et al., 2013). For each of the four analyzed segments of the cycle, the regression procedure assesses which covariates, among the proximal and distal explanatory factors, are significantly related to the stage responsibility for food waste (dependent phase variable). At each step, the influences of the previous phases on the role of the currently modeled phase are included as potentially additional explanatory variables.

Secondly, the study further develops six specific partial proportional odds regression models (PPOM) (Peterson and Harrell, 1990) to rank the phases of consumers' food choice cycle according to their contribution to household waste for each selected food item. The models identify and measure the relationships between a set of covariates (e.g., phase variables and distal explanatory factors) and the dependent level of (ordinal frequency of) household food waste (Fig. 1). 


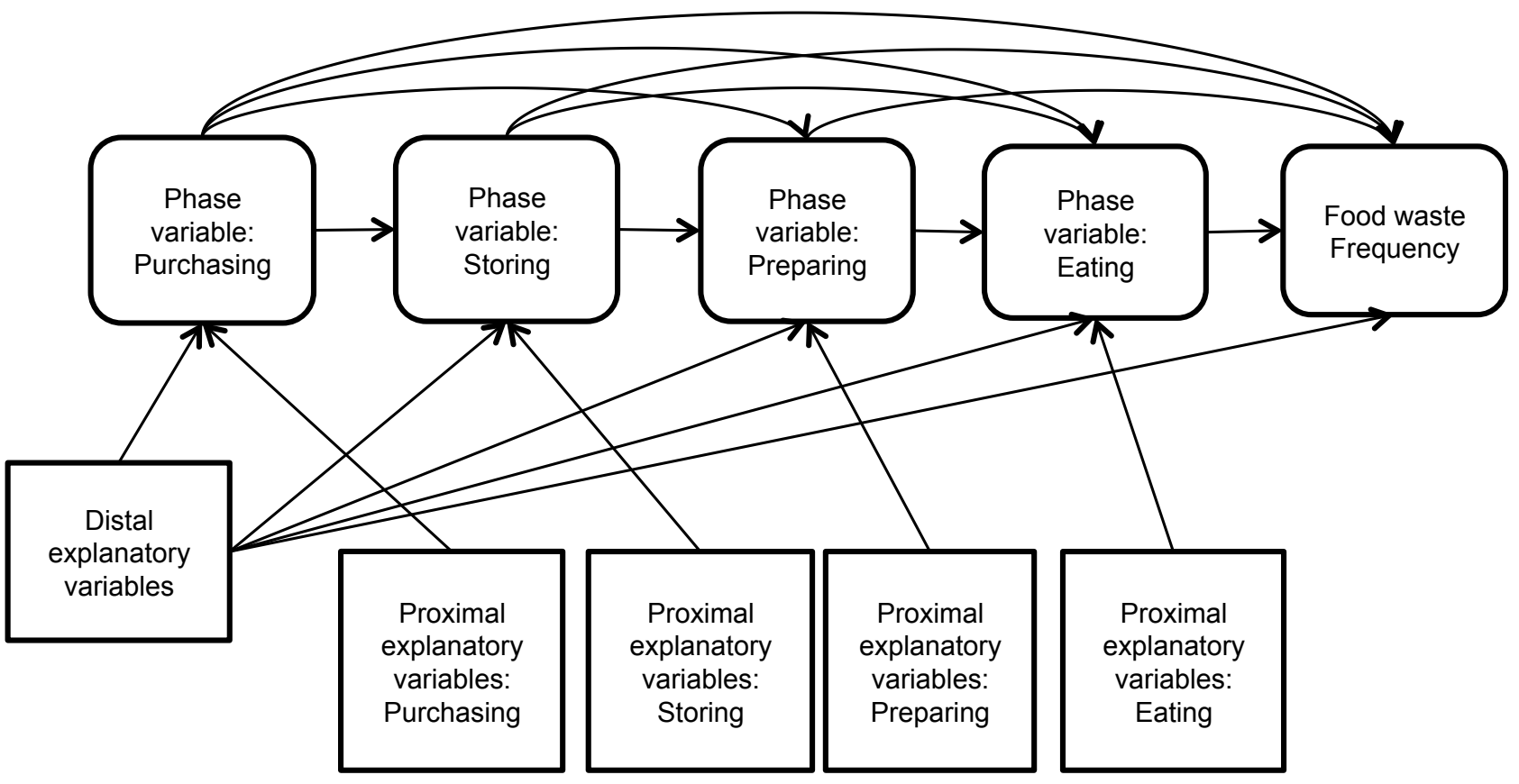

Fig. 1. Consumer's food waste cycle and path diagram: regression models framework

The use of the PPOM concepts is motivated by their coherence with the odds assumption and nature of the modeled variables. Conversely, the standard statistical modeling technique for ordinal response variables, namely the proportional odds model (POM or ordinal logistic model), may not ensure the coherence of the results with the major proportional odds assumption. The PPOM framework is preferred since odds ratios related to certain explanatory variables are not restricted to being equal for all the increasing levels of the ordinal response variable (Peterson and Harrell, 1990).

According to these considerations, a PPOM is developed for each food category by adopting a three-stage procedure:

1. implement the PPOM that includes non-proportional odds for all explanatory variables;

2. identify explanatory variables by means of statistical hypothesis tests to assess the equivalence of odds ratios that satisfy the proportional odds assumption; and

3. develop the PPOM considering only non-proportional odds explanatory variables identified in the previous stage.

For all the regression models, the significant results indicate odds ratio (OR) values with $95 \%$ confidence intervals $(\mathrm{Cl})$. For the logistic models, the odds ratios represent multiplicative coefficients on the odds of the related phase variable generating household food waste. In the case of PPOMs, the odds ratios describe multiplicative coefficients on the odds of the higher level of food waste frequency in the home (e.g., often). In particular, two odds ratios are considered when PPOMs measure non-proportional odds explanatory variables. The first OR compares food waste frequency (response level) "often" with "sometimes" or "never," while the second OR compares "often" or "sometimes" with "never".

An OR value of less than one indicates that the associated category of explanatory variables has a lower frequency of household food waste than that of the reference category. For each logistic and partial proportional odds model, the goodness-of-fit is measured using general chisquare statistic and associated p-values, which ascertain the adherence to the stated assumption and significance of the results. 


\section{Results}

The respondents are equally distributed by gender and mainly belong to the central classes in terms of household size and age (e.g., 2-4 family members and 35-64 years; see Table 6 in the Appendix). Approximately $54 \%$ of the respondents hold a secondary education diploma, while $26 \%$ completed a primary education, and the remaining $20 \%$ had a university degree. Although perceived monetary wealth marginally improves during the observed period, about $60 \%$ of the respondents mention difficult economic conditions.

Several patterns emerge for main food routines and behaviors (proximal variables; Table 6 , Appendix): shopping lists represent a tool regularly adopted by about $50 \%$ of the respondents, frequency of shopping is relatively high ( $2-3$ times per week and every 2 days for about $50 \%$ ), seasonal and local food products are largely preferred, and special offers are often prioritized. Although the respondents attest-in their large majority-a general concern regarding generation of food waste in the home, the frequency of waste increases during the analyzed three-year period and reaches high values for a large share of the respondents and different food products (see Table 8 in the Appendix). These results reveal that $65 \%$ of respondents (sometimes or often) discard fruits and vegetables. With a similar frequency of waste, $35 \%-38 \%$ respondents throw away their dairy products and bread and about $30 \%$ wasted cold cuts and eggs.

Considering the connection between the purchasing phase and food waste generation, the logistic model emphasizes the role of both distal and proximal explanatory factors of provisioning food play (Table 1). On the one hand, a more active attitude toward food waste prevention characterizes the members of larger households. This is revealed by the adoption of specific measures during the provisioning phase such as the use of shopping lists. On the other hand, the concentration of shopping responsibility on a single person and preference accorded to special offers and out-of-season products are the main constitutive variables that make the purchasing stage a driver of food waste.

The findings for the storing phase highlight a positive relationship between in-home food stockpiling and waste generation: the higher the amount of food stored, the greater the waste (Table 2). This is influenced by different categories of distal factors such as household size and education level. Put differently, other storing routines and behaviors, such as the use of expired foodstuffs and adoption of sustainable food management practices, constitute concrete actions in the fight against food waste. In the preparing phase, food waste drivers present significant regional differences: for instance, consumers living in the central and southern regions tend to discard food more frequently while cooking (Table 3). In addition, there is a strong relationship between large household groups and food waste generation during food preparation, whereas family size does not have a considerable effect on final consumption (eating phase; Table 4).

The different stages of consumers' food cycle present well-identifiable characteristics with specific food waste drivers and overall, show a clear pattern of inter-relationships (phase variables; see Tables 2-4). As for food waste generation within households, food purchasing significantly influences the contribution of the preparation phase. In turn, the preparation phase affects eating activities, whereas storing is deemed an independent phase with limited linkages with other segments of the food cycle.

Considering both the phase and distal variables, the series of PPOMs developed by this study identifies the main determinants of the in-home waste frequency of six selected foodstuffs, and enables comparisons among the roles each behavioral phase plays (Table 5; see also Tables 914 in the Appendix). According to some recent studies (Section 2), the results show that purchasing followed by preparing are the key phases of household food waste generation for all the analyzed products. Storing, on the other hand, limits its influence to lower frequency cases of 
345 waste (i.e., sometimes) and acts as a waste-preventing phase for the more perishable products 346 (i.e., dairies, fruits and vegetables, and cold cuts). Finally, eating is a significant driving phase only 347 for the waste of fresh bread in the home. 
Table 1. Logistic model: "Planning/Purchasing" phase's drivers of household food waste.

\begin{tabular}{|c|c|c|c|c|c|}
\hline Variable & Category & Reference & OR & $95 \% \mathrm{Cl}$ & P-value \\
\hline \multirow[t]{2}{*}{ Use of shopping list } & Sometimes & \multirow[t]{2}{*}{ Never } & 0.98 & $(0.77-1.25)$ & 0.8903 \\
\hline & Always & & 0.67 & $(0.53-0.86)$ & 0.0013 \\
\hline \multirow{4}{*}{$\begin{array}{l}\text { Weekly household food } \\
\text { expenditure }\end{array}$} & $50-100 €$ & \multirow[t]{4}{*}{$0-50 €$} & 1.39 & $(1.11-1.73)$ & 0.0041 \\
\hline & $100-200 €$ & & 1.63 & $(1.28-2.07)$ & $<.0001$ \\
\hline & $200-300 €$ & & 1.75 & $(1.27-2.41)$ & 0.0006 \\
\hline & More than $300 €$ & & 1.94 & $(1.19-3.14)$ & 0.0074 \\
\hline \multirow{2}{*}{$\begin{array}{l}\text { Take advantage of special } \\
\text { offers }\end{array}$} & Often & \multirow{2}{*}{$\begin{array}{l}\text { Sometimes / } \\
\text { Never }\end{array}$} & 1.27 & $(1.06-1.53)$ & 0.0088 \\
\hline & Always & & 1.13 & $(0.94-1.37)$ & 0.1983 \\
\hline $\begin{array}{l}\text { Person responsible for } \\
\text { shopping }\end{array}$ & Always the same & Different & 1.23 & $(1.05-1.45)$ & 0.0104 \\
\hline \multirow[t]{2}{*}{ Shopping strategy } & Pragmatic & \multirow[t]{2}{*}{ Low-cost } & 1.02 & $(0.77-1.34)$ & 0.8886 \\
\hline & High quality & & 1.18 & $(0.88-1.59)$ & 0.2676 \\
\hline \multirow[t]{4}{*}{ Frequency of food shopping } & Every 2 days & \multirow[t]{4}{*}{ Every day } & 1.22 & $(0.90-1.65)$ & 0.1978 \\
\hline & 2/3 times per week & & 1.09 & $(0.81-1.48)$ & 0.5766 \\
\hline & 1 time per week & & 1.42 & $(1.02-1.99)$ & 0.0394 \\
\hline & Every 15 days or more & & 1.09 & $(0.78-1.51)$ & 0.6199 \\
\hline \multirow{3}{*}{$\begin{array}{l}\text { Frequency of non-seasonal } \\
\text { products purchasing }\end{array}$} & Rarely & \multirow[t]{3}{*}{ Never } & 1.66 & $(1.24-2.22)$ & 0.0006 \\
\hline & Sometimes & & 2.43 & $(1.80-3.29)$ & $<.0001$ \\
\hline & Often & & 3.28 & $(2.21-4.85)$ & $<.0001$ \\
\hline \multirow{3}{*}{$\begin{array}{l}\text { Frequency of non-local food } \\
\text { purchasing }\end{array}$} & Rarely & \multirow[t]{3}{*}{ Never } & 0.93 & $(0.70-1.23)$ & 0.5882 \\
\hline & Sometimes & & 0.95 & $(0.71-1.27)$ & 0.7125 \\
\hline & Often & & 0.90 & $(0.62-1.31)$ & 0.5969 \\
\hline Gender & Female & Male & 0.88 & $(0.78-1.00)$ & 0.0523 \\
\hline \multirow[t]{4}{*}{ Macro region } & Center & \multirow[t]{4}{*}{ North-West } & 1.05 & $(0.87-1.26)$ & 0.6364 \\
\hline & Islands & & 0.96 & $(0.77-1.20)$ & 0.7322 \\
\hline & North-East & & 0.94 & $(0.78-1.13)$ & 0.4839 \\
\hline & South & & 1.19 & $(0.99-1.42)$ & 0.0656 \\
\hline \multirow[t]{4}{*}{ Household size } & 2 & \multirow[t]{4}{*}{1} & 0.80 & $(0.64-1.02)$ & 0.0681 \\
\hline & 3 & & 0.84 & $(0.65-1.07)$ & 0.1535 \\
\hline & 4 & & 0.67 & $(0.52-0.87)$ & 0.0023 \\
\hline & $>4$ & & 0.52 & $(0.38-0.72)$ & $<.0001$ \\
\hline \multirow[t]{3}{*}{ Perception of monetary wealth } & Many difficulties & \multirow[t]{3}{*}{ Feeling poor } & 1.36 & $(0.98-1.89)$ & 0.0664 \\
\hline & Some difficulties & & 1.62 & $(1.20-2.20)$ & 0.0018 \\
\hline & Safely & & 1.70 & $(1.24-2.31)$ & 0.0008 \\
\hline \multirow[t]{3}{*}{ Education level } & High school & \multirow{3}{*}{$\begin{array}{l}\text { Primary / } \\
\text { middle school }\end{array}$} & 1.04 & $(0.87-1.23)$ & 0.6895 \\
\hline & Master degree & & 1.20 & $(0.97-1.48)$ & 0.0937 \\
\hline & PHD & & 1.18 & $(0.85-1.62)$ & 0.3228 \\
\hline \multirow[t]{2}{*}{ Age } & $18-34$ & \multirow[t]{2}{*}{$35-64$} & 1.04 & $(0.90-1.22)$ & 0.5936 \\
\hline & $65+$ & & 0.91 & $(0.77-1.09)$ & 0.3171 \\
\hline
\end{tabular}


Table 2. Logistic model: "Storing" phase's drivers of household food waste.

\begin{tabular}{|c|c|c|c|c|c|}
\hline Variable & Category & Reference & OR & $95 \% \mathrm{Cl}$ & $\begin{array}{c}P . \\
\text { value }\end{array}$ \\
\hline Planning/Purchasing phase & Yes & No & 0.51 & $(0.45-0.59)$ & $<.0001$ \\
\hline Person responsible for storing & Always the same & Different & 0.83 & $(0.69-1.00)$ & 0.0438 \\
\hline \multirow[t]{2}{*}{ Use of expired products } & Reuse & \multirow[t]{2}{*}{ Throw away } & 0.79 & $(0.66-0.95)$ & 0.0104 \\
\hline & Other destinations & & 0.52 & $(0.41-0.66)$ & $<.0001$ \\
\hline Gender & Female & Male & 0.94 & $(0.82-1.08)$ & 0.3812 \\
\hline \multirow[t]{4}{*}{ Macro region } & Center & \multirow[t]{4}{*}{ North-West } & 0.90 & $(0.74-1.11)$ & 0.3210 \\
\hline & Islands & & 0.86 & $(0.67-1.10)$ & 0.2263 \\
\hline & North-East & & 0.93 & $(0.76-1.15)$ & 0.5184 \\
\hline & South & & 0.78 & $(0.64-0.95)$ & 0.0123 \\
\hline \multirow[t]{4}{*}{ Household size } & 2 & \multirow[t]{4}{*}{1} & 1.31 & $(1.03-1.66)$ & 0.0283 \\
\hline & 3 & & 1.38 & $(1.08-1.76)$ & 0.0112 \\
\hline & 4 & & 1.08 & $(0.84-1.38)$ & 0.5629 \\
\hline & $>4$ & & 1.67 & $(1.20-2.34)$ & 0.0027 \\
\hline \multirow[t]{3}{*}{ Perception of monetary wealth } & Many difficulties & \multirow[t]{3}{*}{ Feeling poor } & 1.39 & $(1.00-1.92)$ & 0.0493 \\
\hline & Some difficulties & & 1.18 & $(0.88-1.58)$ & 0.2586 \\
\hline & Safely & & 1.12 & $(0.83-1.51)$ & 0.4624 \\
\hline \multirow[t]{3}{*}{ Education level } & High school & \multirow{3}{*}{$\begin{array}{l}\text { Primary / } \\
\text { middle school }\end{array}$} & 1.32 & $(1.10-1.58)$ & 0.0024 \\
\hline & Master degree & & 1.54 & $(1.23-1.94)$ & 0.0002 \\
\hline & PHD & & 1.68 & $(1.17-2.41)$ & 0.0048 \\
\hline \multirow[t]{2}{*}{ Age } & $18-34$ & \multirow[t]{2}{*}{$35-64$} & 0.97 & $(0.82-1.14)$ & 0.6932 \\
\hline & $65+$ & & 0.94 & $(0.77-1.14)$ & 0.5038 \\
\hline
\end{tabular}


Table 3. Logistic model: "Preparing" phase's drivers of household food waste.

\begin{tabular}{|c|c|c|c|c|c|}
\hline Variable & Category & Reference & OR & $95 \% \mathrm{Cl}$ & $\begin{array}{c}P \text { - } \\
\text { value }\end{array}$ \\
\hline Storing phase & Yes & No & 0.93 & $(0.77-1.13)$ & 0.4637 \\
\hline Planning/Purchasing phase & Yes & No & 1.37 & $(1.15-1.63)$ & 0.0005 \\
\hline $\begin{array}{l}\text { Person responsible for } \\
\text { preparing }\end{array}$ & Always the same & Different & 0.98 & $(0.76-1.27)$ & 0.8946 \\
\hline Gender & Female & Male & 0.90 & $(0.76-1.07)$ & 0.2303 \\
\hline \multirow[t]{4}{*}{ Macro region } & Center & \multirow[t]{4}{*}{ North-West } & 1.60 & $(1.22-2.10)$ & 0.0007 \\
\hline & Islands & & 1.66 & $(1.22-2.26)$ & 0.0014 \\
\hline & North-East & & 1.22 & $(0.91-1.62)$ & 0.1807 \\
\hline & South & & 2.11 & $(1.64-2.71)$ & $<.0001$ \\
\hline \multirow[t]{4}{*}{ Household size } & 2 & \multirow[t]{4}{*}{1} & 1.34 & $(0.91-1.99)$ & 0.1439 \\
\hline & 3 & & 2.05 & $(1.39-3.02)$ & 0.0003 \\
\hline & 4 & & 2.62 & $(1.77-3.86)$ & $<.0001$ \\
\hline & $>4$ & & 2.72 & $(1.74-4.24)$ & $<.0001$ \\
\hline \multirow[t]{3}{*}{ Perception of monetary wealth } & Many difficulties & \multirow[t]{3}{*}{ Feeling poor } & 1.03 & $(0.66-1.60)$ & 0.9076 \\
\hline & Some difficulties & & 1.40 & $(0.94-2.10)$ & 0.0988 \\
\hline & Safely & & 1.17 & $(0.78-1.77)$ & 0.4496 \\
\hline \multirow[t]{3}{*}{ Education level } & High school & \multirow{3}{*}{$\begin{array}{l}\text { Primary / } \\
\text { middle school }\end{array}$} & 1.22 & $(0.95-1.55)$ & 0.1177 \\
\hline & Master degree & & 1.22 & $(0.91-1.65)$ & 0.1845 \\
\hline & PHD & & 0.98 & $(0.61-1.58)$ & 0.9482 \\
\hline \multirow[t]{2}{*}{ Age } & $18-34$ & \multirow[t]{2}{*}{$35-64$} & 1.16 & $(0.95-1.42)$ & 0.1381 \\
\hline & $65+$ & & 1.20 & $(0.93-1.55)$ & 0.1546 \\
\hline
\end{tabular}

Goodness-of-fit of the model: Chi-square statistic $=148.3, \mathrm{df}=22, \mathrm{p}$-value $<0.0001$ Bolded odds ratio parameters are statistically significant $(0.05)$. 
Table 4. Logistic model: "Eating” phase's drivers of household food waste.

\begin{tabular}{|c|c|c|c|c|c|}
\hline Variable & Category & Reference & OR & $95 \% \mathrm{Cl}$ & $\begin{array}{c}P- \\
\text { value }\end{array}$ \\
\hline Preparing phase & Yes & No & 2.27 & $(1.58-3.25)$ & $<.0001$ \\
\hline Storing phase & Yes & No & 0.50 & $(0.37-0.69)$ & $<.0001$ \\
\hline Planning/Purchasing phase & Yes & No & 0.79 & $(0.58-1.09)$ & 0.1566 \\
\hline \multirow[t]{4}{*}{ Frequency of lunch at home } & Sometimes & \multirow[t]{4}{*}{ Rarely / Never } & 1.31 & $(0.57-3.00)$ & 0.5289 \\
\hline & Often & & 1.46 & $(0.63-3.35)$ & 0.3754 \\
\hline & Nearly always & & 1.27 & $(0.57-2.84)$ & 0.5533 \\
\hline & Always & & 1.34 & $(0.61-2.95)$ & 0.4667 \\
\hline \multirow[t]{3}{*}{ Frequency of dinner at home } & Often & \multirow{3}{*}{$\begin{array}{l}\text { Sometimes / } \\
\text { Rarely / Never }\end{array}$} & 1.10 & $(0.50-2.40)$ & 0.8169 \\
\hline & Nearly always & & 1.06 & $(0.50-2.22)$ & 0.8832 \\
\hline & Always & & 0.83 & $(0.39-1.78)$ & 0.6361 \\
\hline Gender & Female & Male & 0.80 & $(0.59-1.09)$ & 0.1550 \\
\hline \multirow[t]{4}{*}{ Macro region } & Center & \multirow[t]{4}{*}{ North-West } & 0.66 & $(0.39-1.11)$ & 0.1169 \\
\hline & Islands & & 1.52 & $(0.92-2.51)$ & 0.1035 \\
\hline & North-East & & 1.05 & $(0.66-1.68)$ & 0.8405 \\
\hline & South & & 1.30 & $(0.84-2.01)$ & 0.2382 \\
\hline \multirow[t]{4}{*}{ Household size } & 2 & \multirow[t]{4}{*}{1} & 0.50 & $(0.30-0.83)$ & 0.0071 \\
\hline & 3 & & 0.70 & $(0.42-1.14)$ & 0.1519 \\
\hline & 4 & & 0.55 & $(0.32-0.93)$ & 0.0265 \\
\hline & $>4$ & & 0.84 & $(0.44-1.60)$ & 0.5901 \\
\hline \multirow[t]{3}{*}{ Perception of monetary wealth } & Many difficulties & \multirow[t]{3}{*}{ Feeling poor } & 1.04 & $(0.52-2.12)$ & 0.9059 \\
\hline & Some difficulties & & 0.80 & $(0.42-1.54)$ & 0.5076 \\
\hline & Safely & & 1.07 & $(0.56-2.07)$ & 0.8339 \\
\hline \multirow[t]{3}{*}{ Education level } & High school & \multirow{3}{*}{$\begin{array}{l}\text { Primary / middle } \\
\text { school }\end{array}$} & 0.76 & $(0.51-1.13)$ & 0.1694 \\
\hline & Master degree & & 0.81 & $(0.50-1.34)$ & 0.4147 \\
\hline & PHD & & 0.50 & $(0.20-1.24)$ & 0.1345 \\
\hline \multirow[t]{2}{*}{ Age } & $18-34$ & \multirow[t]{2}{*}{$35-64$} & 1.09 & $(0.75-1.59)$ & 0.6548 \\
\hline & $65+$ & & 1.51 & $(1.00-2.30)$ & 0.0524 \\
\hline
\end{tabular}

Goodness-of-fit of the model: Chi-square statistic $=75.2, \mathrm{df}=29, \mathrm{p}$-value $<0.0001$ Bolded odds ratio parameters are statistically significant (0.05).

Table 5. Partial Proportional Odds Model: phase variables and waste frequencies per food category.

\begin{tabular}{|c|c|c|c|c|c|c|c|}
\hline \multirow[t]{2}{*}{ Phase variable } & \multirow[t]{2}{*}{ Response level } & \multicolumn{6}{|c|}{ Odds Ratio } \\
\hline & & $\begin{array}{l}\text { Fresh } \\
\text { bread }\end{array}$ & Cheese & $\begin{array}{l}\text { Vegetables } \\
\text { and Fruits }\end{array}$ & $\begin{array}{l}\text { Milk and } \\
\text { Yoghurt }\end{array}$ & $\begin{array}{l}\text { Cold } \\
\text { cuts }\end{array}$ & Eggs \\
\hline $\begin{array}{l}\text { Planning/Purchasing } \\
\text { phase }\end{array}$ & Both & 2.62 & 2.80 & 3.19 & 2.59 & 2.81 & 2.92 \\
\hline \multirow[t]{2}{*}{ Storing phase } & $\begin{array}{l}\text { Often vs. } \\
\text { Sometimes/Never }\end{array}$ & - & 0.55 & - & 0.65 & 0.53 & 0.53 \\
\hline & $\begin{array}{l}\text { Often/Sometimes } \\
\text { vs. Never }\end{array}$ & - & 1.54 & 2.97 & 1.30 & 1.32 & - \\
\hline Preparing phase & Both & 2.56 & 1.86 & 1.81 & 1.57 & 2.05 & 1.47 \\
\hline Eating phase & Both & 1.41 & - & - & - & - & - \\
\hline
\end{tabular}

Notes: non-statistically significant Odds Ratios (>0.05) are not reported. 


\section{Discussion}

According to recent studies (Section 2), the results emphasize the complex structure of consumers' food cycle while suggesting a potential ranking for its behavioral phases in their contribution to the frequency of household food waste. The most upstream stage, provisioning, exerts the highest influence on the generation of household food waste. The distance between choice and outcome offers key implications at both the individual and situational level. At the individual level, this gap delivers an additional element of uncertainty to consumers' decisionmaking. Because of the early and crucial food choice made during the purchasing stage, there is a time lapse in the generation of household food waste. The measure of this behavior-outcome gap is a subjective perception rather than an ordinary temporal scale (Lapinski et al. 2005). The highest odd ratio value reached by the planning/purchasing stage for the most perishable foodstuffs (i.e., wasted fruits and vegetables; see Table 11 in the Appendix) supports this assumption.

The time interval between food-provisioning behavior and the resulting waste emphasizes the challenge consumers face when making their decision in response to their priorities. This limited capacity to deal with this ultimate effect of the food behavior adds risk to the related process of choice as a whole. According to TPB, the uncertainty that emerges from the behavior-outcome gap is in fact envisaged to affect the cognitive determinants of an individual's decision-making. Consumers perceive food waste as a weak effect of the purchasing choice. Thus, the first component of the behavioral beliefs (the subjective probability that a decision produces the consequence) is rendered enfeebled. The identification of this early behavioral precursor leads to two main considerations. Firstly, it offers a possible explanation for the debated role of an unfavorable attitude-its immediate descendant-toward food waste in food behaviors (Section 2). While numerous studies ascertain the potential contribution that these attitudes can deliver to the prevention and reduction of food waste, it is recognized that they are not sufficient to fight food waste (i.e., contextual factors are pivotal to this goal) and they often do not denote food behavior. Secondly, because the identified factual gap squeezes the first component of the behavioral beliefs-perception of consequence-it appears necessary to boost the second element, subjective evaluation of outcome. According to this objective, initiatives aimed at enhancing knowledge about the food waste domain can determine a positive cascade effect on the related behavioral belief, attitude, motivation, and behavior (food purchasing).

Without adequate interventions, the uncertainty generated from the behavior-outcome (factual) gap not only merges with that caused by the intention-behavior (cognitive) gap but also propagates (through behavioral beliefs) along an individual's decision-making like a constitutive condition. Accounting for the hidden and repetitive characteristics of food waste-related choices, a possible personal strategy that consumers can implement to face this cumulated uncertainty is the greater use of heuristics. In the field of behavioral economics, the literature shows a large spectrum of evidence and variables explaining the deviation of individuals' choices from the standard economic model. To this effect, the emerged primary role of purchasing in the consumers' food waste cycle allows for the identification of the main coherent, non-standard food behavioral patterns.

As for the classification proposed by DellaVigna (2009), the first group of deviations is related to non-standard beliefs. Because of the (factual) gap between the dominant early-stage food choice (purchasing) and expected outcome (food waste), consumers are inclined to identify their future preferences with the current ones. This, however, forms projection biases (Read and van Leeuwen, 1998).

A second class of deviations is represented by non-standard preferences. Since food waste is conditioned by a considerable delay with respect to its driving choice (provisioning), when expected alternative rewards are compared and evaluated, individuals may demonstrate timeinconsistent preferences. This can be the case of ensuring food security against avoiding wastes in the home when consumers are inclined to prioritize food security and consequently, to purchase 
commensurate volumes of food (Stephen and Loewenstein, 1991; Frederick et al., 2002). Moreover, consumers reveal risk preferences when they evaluate a food choice by comparing losses and gains. The purchasing stage can influence the framing of possible outcomes such as food-related status concerns ("reference point"), which is an alternative to the household waste prevention target. The repartition of utility into substitutive components can lead individuals to adopt probabilistic schemes that overweight losses (status erosion), subordinate alternatives (food waste reduction), and favor risk-aversion behaviors (Kahneman and Tversky, 1979).

Non-standard decision-making characterizes the third class of deviations. During provisioning, when the most influential decisions are made, consumers are exposed to diverse information and complex choices. To simplify their decision-making process, individuals could use different types of sub-optimal heuristics such as orienting their choice to familiarity and identity criteria (habits; Verplanken and Orbell, 2003), preselecting available information (limited attention), or referring to the most noticeable elements of alternative options (salience). To this effect, the weight of the relationship between "person responsible for shopping" and purchasing phase (source of household food waste) suggests that this typology of consumers could be inclined to resort to nonstandard routines when buying food. By contrast, larger-sized households report higher food waste frequency, which appears mainly due to mismanagement of food practices in the downstream phases (e.g., storing and preparing ones) rather than to adoption of heuristics at the provisioning.

At the situational level, since in the purchasing stage individuals make the most critical choices in terms of generation of food waste within the household, understanding consumers' uncertainty requires extending the analysis to influences exerted in out-of-home contexts (Evans, 2012, 2011). In particular, throughout provisioning, individuals make subjective judgments contingent on the conditions at the food retail level and (potential) mutual exposure to other consumers' behavior. Since the purchasing phase is crucial for the food waste pattern, its quasi-social dimension should contribute to moderating the related behavioral-outcome gap. The literature focused on household food waste and the motivation-behavior gap shows that social norms could affect food wasterelated intentions; however, the complexity of the subject reveals additional specific elements. While Quested et al. (2013) assume that social norms exert a limited influence on the-scarcely visible-household food waste, Graham-Rowe et al. (2014) identify "a lack of perceived social pressure" as a barrier to the consumers' intention to reduce the food waste. Further, there is no evidence on the relationship between awareness about other individuals' food waste countermeasures (descriptive norms) and individual's motivation to replicate it. Nevertheless, there is a significant association with the perception of what the others think (injunctive norms; GrahamRowe et al., 2015; Stancu et al., 2016).

According to Aschemann-Witzel et al. (2017) and Lee (2018), the findings of this study demonstrate that the contextual factors (e.g., retailers' special offers and purchase frequency of non-seasonal products) are significant when modeling the contribution of the provisioning phase to the generation of food waste within the household. In particular, this is proved by the significant contradiction between the respondents' self-assessed general concern for food waste and the increase in waste frequency during the study period. Moreover, this positive trend and long-lasting pre-eminence of the purchasing stage as the major source of waste behavior in homes (factual gap) suggest a persistency in consumers' uncertainty.

\section{Conclusions}

Purchasing emerges as the most crucial consumer choice for the generation of food waste in the household and it became increasingly important during the three-year period covered by the survey. 
The first theoretical contribution derived from this main findings is the detection of a distance between behavior and outcome. While the literature has largely focused on a motivationbehavior (cognitive) gap, this study shows an additional (factual) gap in consumer's decisionmaking, which raises the complexity of the food waste domain. Unclear and deferred consequences, such as to avoid discarding edible products at home, can be a detrimental to the originating food decision when compared to alternatives leading to clearly recognizable and near results. This is particularly significant when consumers deal with food waste-related choices influenced by concurrent outcomes, such as timing, risk, and social factors. In other words, it is a set of converging elements that deliver uncertainty and weaken waste-adverse attitudes.

Indeed, the identification of the purchasing action as the most influential for the generation of household food waste underlines that this choice is part of a complex series of interrelated behavioral precursors. To the effect of TPB, this study suggests that the behavior-outcome gap and resultant uncertainty can have a feedback influence on individuals' behavioral beliefs. The second theoretical contribution of this study is the detection of the most relevant behavioral precursor in tackling food waste generation. In particular, the revealed factual gap compresses the subjective perception of the behavioral effect (i.e., awareness of food waste). Therefore, it is the other component of the behavioral beliefs-the subjective evaluation of outcome (i.e., knowledge)-the earliest behavioral antecedent that can lead to more robust behavioral beliefs and attitudes against food waste. Without initiatives supporting knowledge of the food field, uncertainty can further diffuse across an individual's overall decision-making process and become a constitutive driver of food waste. Moreover, because the food-related experiences of other individuals are, generally, not visible and therefore, not helpful in orienting or modifying the decisions and reducing uncertainty, consumers are more likely to resort to heuristics.

The third important theoretical contribution of this work is the analysis of household food waste represented by the extension of the TPB approach to a series of individuals' not rational food-related decisions through the lens of behavioral economics. Considering the role of provisioning, this study suggests the main non-standard behavioral patterns (e.g., projection biases, risk preferences, and salience) that can influence food waste generation. The centrality of the purchasing stage and the deriving behavior-outcome gap highlight that consumers' uncertainty is the foremost obstacle to preventing household food waste. This leads to a two-fold order of implications.

At the individual level, the need to limit uncertainty and use of heuristics require the enhancing of consumers' knowledge of food waste and, in general, the boosting of food culture. These leverages should favor the correct assessment of food waste repercussions and, in turn, form responsible behavioral beliefs and mature attitudes toward food waste prevention and reduction. With this aim, concrete interventions should prioritize educational programs targeted at students and informative campaigns at the food retail level by operators and experts of the supply chains. Furthermore, given the importance of provisioning behaviors demonstrated by consumers in out-of-home contexts (food retail), additional research efforts should be oriented toward analyzing the role of social norms (normative beliefs) in influencing the individuals' purchase decisions in relation to food waste. Given this objective, laboratory and field experiments focused on food-provisioning situations should investigate consumers' deviations from standard behaviors with reference to the role of both social preferences (e.g., responsible behaviors; Forsythe et al., 1994) and social pressures (e.g., other individuals' choices and retailers' options; Abrahamse and Steg, 2013; Young et al., 2017) in food decision-making.

Finally, at food retail level, it is necessary to transform related situational features from the source of uncertainty into opportunities of strengthening customers' understanding of food values and a guiding framework for coherent food behaviors. Negotiated voluntary agreements engaging retailers and consumers could stimulate multi-stakeholder governance and corporate social 
517 responsibility patterns. They could also represent the structural condition to favor sustainable food 518 purchasing choices and joint solutions to address household food waste. 
Abrahamse, W., and Steg, L., 2013. Social influence approaches to encourage resource conservation: a meta-analysis. Global http://dx.doi.org/10.1016/j.gloenvcha.2013.07.029.

Environ. Change, 23, 1773-1785,

Ajzen, I., 1991. The theory of planned behavior. Organizational Behavior and Human Decision Processes, 50(2), 179-211.

Ajzen, I., 2015. Consumer attitudes and behavior: the theory of planned behavior applied to food consumption decisions. Rivista di Economia Agraria, (LXX) 2, 121-138, http://dx.doi.org/10.13128/REA-18003.

Aschemann-Witzel, J., Jensen, J.H., Jensen, M.H., and Kulikovskaja, V., 2017. Key characteristics and success factors of supply chain initiatives tackling consumer-related food waste - A multiple case study. Appetite, 116, 246-258, http://dx.doi.org/10.1016/j.appet.2017.05.013.

Borger, T., and Hattam, C., 2017. Motivations matter: Behavioural determinants of preferences for remote and unfamiliar environmental goods. Ecological Economics, 131, 64-74, http://dx.doi.org/10.1016/j.ecolecon.2016.08.021.

Brook Lyndhurst, 2007. Food behaviour consumer research findings from the quantitative survey, WRAP-UK Briefing Paper.

Canali, M., Amani, P., Aramyan, L., Gheoldus, M., Moates, G., Östergren, K., Silvennoinen, K., Waldron, K., Vittuari, M., 2017. Food Waste Drivers in Europe, from Identification to Possible Interventions. Sustainability, 9(1), 37, http://www.mdpi.com/2071-1050/9/1/37.

Diaz-Ruiz, R., Costa-Font, M., and Gil, J.M., 2018. Moving ahead from food-related behaviours: an alternative approach to understand household food waste generation. Journal of Cleaner Production, 172, 1140-1151, https://doi.org/10.1016/j.jclepro.2017.10.148.

Evans, D., 2011. Blaming the consumer - once again: the social and material contexts of everyday food waste practices in some English households. Critical Public Health, 21, 429-540, http://dx.doi.org/10.1080/09581596.2011.608797.

Evans, D., 2012. Beyond the throwaway society: ordinary domestic practice and a sociological approach to household food waste. Sociology, 46, 41-56, http://dx.doi.org/10.1177/0038038511416150.

FAO, 2001. Global food waste and food losses, http://www.fao.org/docrep/014/mb060e/mb060e.pdf.

Farr-Wharton, G., Foth, M., and Hee-Jehong Choi, J., 2014. Identifying factors that promote consumer behaviours causing expired domestic food waste. Journal of Consumer Behaviour, 13, 393-402, https://doi.org/10.1002/cb.1488.

Festinger, L., Riecken, H.W., and Schachter, S., 1956. When Prophecy Fails: A Social and Psychological Study of a Modern Group that Predicted the Destruction of the World. Minneapolis: University of Minnesota Press.

Forsythe, R., Horowitz, J.L., Savin, N.E., and Sefton, M., 1994. Fairness in Simple Bargaining Experiments. Games and Economic Behavior, 6(3), 347-369, http://econpapers.repec.org/RePEc:eee:gamebe:v:6:y:1994:i:3:p:347-369.

Frederick, S., Loewenstein, G., and O'Donoghue, T., 2002. Time Discounting and Time Preference: A Critical Review. Journal of Economic Literature, 40(2), 351-401, 
http://EconPapers.repec.org/RePEc:aea:jeclit:v:40:y:2002:i:2:p:351-401.

Gerasimou, G., 2016. Asymmetric dominance, deferral, and status quo bias in a behavioral model of choice. Theory and Decision, 80, 295-312, https://link.springer.com/article/10.1007/s11238-0159499-7.

Gjerres, M., and Gaiani, S., 2013. Household food waste in Nordic countries: Estimations and ethical implications. Etik i Praksis (Nord. J. Appl. Ethics), 7, 6-23, http://dx.doi.org/10.5324/eip.v7i1.1786.

Graham-Rowe, E., Jessop, D.C., and Sparks, P., 2014. Identifying motivations and barriers to minimising household food waste. Resources, Conservation and Recycling, 84, 15-23, http://dx.doi.org/10.1016/j.resconrec.2013.12.005.

Graham-Rowe, E., Jessop, D.C., and Sparks, P., 2015. Predicting household food waste reduction using an extended theory of planned behaviour. Resources, Conservation and Recycling, 101, 194-202, http://dx.doi.org/10.1016/j.resconrec.2015.05.020.

Griffin, M., Sobal, J., and Lyson, T.A., 2009. An analysis of a community food waste stream. Agriculture Human Values, 26(1-2), 67-81, https://link.springer.com/article/10.1007\%2Fs10460-008-9178-1.

Gunders, D., 2012. Wasted: How America Is Losing Up to 40 Percent of Its Food from Farm to Fork to Landfill Getting food, Natural Resources Defence Council, Issue paper IP 12-06-B.

Gustavsson, J., Cederberg, C., Sonesson, U., van Otterdijk, R., and Meybeck, A., 2011. Global Food Losses and Food Waste - extent, causes and prevention. FAO, Rome.

Hebrok, M., and Boks, C., 2017. Household food waste: Drivers and potential intervention points for design - An extensive review. Journal of Cleaner Production, 151, 380-392, http://dx.doi.org/10.1016/j.jclepro.2017.03.069.

van Holsteijn, F., and Kemna, R., 2018. Minimizing food waste by improving storing conditions in household refrigerators. Resources, Conservation \& Recycling, 128, 25-31, http://dx.doi.org/10.1016/j.resconrec.2017.09.012.

van der Horst, K., 2012. Overcoming picky eating. Eating enjoyment as a central aspect of children's eating behaviors. Appetite, 58, 567-574, https://doi.org/10.1016/j.appet.2011.12.019.

Hosmer, D.W., Lemeshow, S., and Sturdivant, R.X., 2013. Applied Logistic Regression. Ed. Wiley, New York.

Kahneman, D., and Tversky, A., 1979. "Prospect Theory: An Analysis of Decision under Risk". Econometrica, $47(2)$, 263-91, http://econpapers.repec.org/RePEc:ecm:emetrp:v:47:y:1979:i:2:p:263-91.

Kahneman, D., Knetsch, J.L., and Thaler, R.H., 1991. Anomalies: The Endowment Effect, Loss Aversion, and Status Quo Bias. Journal of Economic Perspectives, 5(1) 193-206, https://www.aeaweb.org/articles?id=10.1257/jep.5.1.193.

Kiesling, E., Günther, M., Stummer, C., and Wakolbinger, L.M., 2012. Agent-based simulation of innovation diffusion: a review. CEJOR, 20(2), 183-230, http://dx.doi.org/10.1007/s10100-0110210-y.

Kriflik, L.S., and Yeatman, H., 2005. Food scares and sustainability: A consumer perspective. Health Risk Soc., 7, 11-24, http://dx.doi.org/10.1080/13698570500042439. 
Lapinski, M.K., and Rimal, R.N., 2005. An explication of social norms. Communication Theory, 15, 127-147, http://onlinelibrary.wiley.com/doi/10.1111/j.1468-2885.2005.tb00329.x/abstract.

Lee, K.C.L., 2018. Grocery shopping, food waste, and the retail landscape of cities: The case of Seoul. Journal of Cleaner Production, 172, 325-334, https://doi.org/10.1016/j.jclepro.2017.10.085.

Loewenstein, G., 1996. Out of control: Visceral influences on behavior. Organizational behavior and human decision processes, 65, 272-292, https://www.andrew.cmu.edu/user/gl20/GeorgeLoewenstein/Papers_files/pdf/Outofcontrol.pdf.

Mondéjar-Jiménez, J.-A., Ferrari, G., Secondi, L., and Principato, L., 2016. From the table to waste: An exploratory study on behaviour towards food waste of Spanish and Italian youths. Journal of Cleaner Production, 138, 8-18, http://dx.doi.org/10.1016/j.jclepro.2016.06.018.

Mueller, R.O., 1996. Basic Principles of Structural Equation Modeling. Ed. Springer, New York.

Neff, R.A., Spiker, M.L., and Truant, P.L., 2015. Wasted Food: U.S. Consumers' Reported Awareness, Attitudes, and behaviors. PLoS ONE, 10 (6), http://journals. plos.org/plosone/article?id=10.1371/journal. pone.0127881.

Parfitt, J., Barthel, M., and MacNaughton, S., 2010. Food waste within food supply chains: Quantification and potential for change to 2050, Philosophical Transactions of the Royal Society $B$ - Biological Sciences, 365 (1554), 3065-3081, http://dx.doi.org/10.1098/rstb.2010.0126.

Parizeau, K., von Massow, M., and Martin, R., 2015. Household-level dynamics of food waste production and related beliefs, attitudes, and behaviours in Guelph, Ontario. Waste Management, 35, 207-217, https://doi.org/10.1016/j.wasman.2014.09.019.

Peterson, B., and Harrell, F.E., 1990. Partial Proportional Odds Models for Ordinal Response Variables. Journal of the Royal Statistical Society, Series C (Applied Statistics), 39(2), 205-217.

Ponis. S.T., Papanikolau, P.-A., Katimertzoglou, P., Ntalla, A.C., and Xenos, K.I., 2017. Household food waste in Greece: A questionnaire survey. Journal of Cleaner Production, 149, 1268-1277, http://dx.doi.org/10.1016/j.jclepro.2017.02.165.

Quested, T.E., Marsh, E., Stunell, D., and Parry, A.D., 2013. Spaghetti soup: The complex world of food waste behaviours. Resources, Conservation and Recycling, 79, 43-51, http://dx.doi.org/10.1016/j.resconrec.2013.04.011.

Read, D., and van Leeuwen, B., 1998. Predicting Hunger: The Effects of Appetite and Delay on Choice. Organizational Behavior and Human Decision Processes, 76(2), 189-205, http://econpapers.repec.org/RePEc:eee:jobhdp:v:76:y:1998:i:2:p:189-205.

Russell, S.V., Young, C.W., Unsworth, K.L., and Robinson, C., 2017. Bringing habits and emotions into food waste behavior. Resources, Conservation \& Recycling, 125, 107-114, http://dx.doi.org/10.1016/j.resconrec.2017.06.007.

Schluter, M., Baeza, A., Dressler, G., Frank, K., Groeneveld, J., Jager, W., Janssen, M.A., McAllister, M.M.J., Muller, B., Orach, K., Schwarz, N., and Wijermans, N., 2017. A framework for mapping and comparing behavioral theories in models of social-ecological systems. Ecological Economics, 131, 21-35, http://dx.doi.org/10.1016/j.ecolecon.2016.08.008.

Setti, M., Falasconi, L., Segrè, A., Cusano, I., and Vittuari, M., 2016. Italian consumers' income and food waste behavior. British Food Journal, 118(7), 1731-1746, http://dx.doi.org/10.1108/BFJ11-2015-0427. 
Stancu, V., Haugaard, P., and Lähteenmäki, L., 2016. Determinants of consumer food waste behaviour: Two routes to food waste. Appetite, 96, 7-17, http://dx.doi.org/10.1016/j.appet.2015.08.025.

Stefan, V., van Herpen, E., Tudoran, A.A., and Lähteenmäki, L., 2013. Avoiding food waste by Romanian consumers: The importance of planning and shopping routines. Food Quality and Preference, 28, 375-381, http://dx.doi.org/10.1016/j.foodqual.2012.11.001.

681

Stenmarck, A., Jensen, C., Quested, T., and Moates, G., 2016. Estimates of European food waste levels, FUSIONS project, ISBN: 978-91-88319-01-2.

Stephen, H., and Loewenstein, G., 1991. Time Inconsistent Preferences and Consumer Self Control. Journal of Consumer Research, 17, 492-506, http://econpapers.repec.org/RePEc:oup:jconrs:v:17:y:1991:i:4:p:492-507.

Stern, P.C., Dietz, T., Abel, T., Guagnano, G.A., and Kalof, L., 1999. A value-belief-norm theory of support for social movements: the case of environmentalism. Human Ecology Review, 6(2), 81-97, http://citeseerx.ist.psu.edu/viewdoc/download?doi=10.1.1.195.5410\&rep=rep1\&type=pdf.

Thøgersen, J., 2014. The mediated influences of perceived norms on pro-environmental behavior. Revue D’Economie Politique 124 (2), 179-193, https://www.cairn.info/revue-d-economie-politique2014-2-page-179.htm.

\section{Ventour, L., 2008. The Food We Waste. WRAP, Banbury/Oxon.}

Vermeir, I., and Verbeke, W., 2006. Sustainable food consumption: exploring the consumer "attitude-behavioral intention" gap. Journal of Agricultural and Environmental Ethics, 19(2), 169194, https://link.springer.com/article/10.1007/s10806-005-5485-3.

Verplanken, B., Aarts, H., van Knippenberg, A., and Moonen, A., 1998. Habit versus planned behaviour: a field experiment. Br. J. Soc. Psychol., 37 (1), 111-128, http://dx.doi.org/10.1111/j.2044-8309.1998.tb01160.x.

Verplanken, B., and Orbell, S., 2003. Reflections on past behavior: a self-report index of habit strength. Journal of Applied Social Psychology, 33(6), 1313-1330, http://dx.doi.org/10.1111/j.15591816.2003.tb01951.x.

Visschers, V.H.M., Wickli, N., and Siegrist, M., 2016. Sorting out food waste behaviour: A survey on the motivators and barriers of self-reported amounts of food waste in households. Journal of Environmental Psychology, 45, 66-78, http://dx.doi.org/10.1016/j.jenvp.2015.11.007.

Watson, M., and Meah, A., 2013. Food, waste and safety: Negotiating conflicting social anxieties into the practices of domestic provisioning. The Sociological Review, 60, 102-120, http://dx.doi.org/10.1111/1467-954x.12040.

WRAP, 2011. Sustainable food - written evidence. House of Commons - Environmental Audit Committee - $\quad$ Publications SF31, http://www.publications.parliament.uk/pa/cm201011/cmselect/cmenvaud/writev/food/m31.htm.

WRAP, 2014. Household food and drink waste: A people focus. Banbury, UK, ISBN 978-1-84405470-1.

Wright, S., 1934. The method of path coefficients. Annals of Mathematical Statistics, 5(3), 161-215.

Young, W., Russell, S.V., Robinson, C.A., and Barkemeyer, R., 2017. Can social media be a tool for reducing consumers' food waste? A behaviour change experiment by a UK retailer. Resources, Conservation and Recycling, 117, 195-203, http://dx.doi.org/10.1016/j.resconrec.2016.10.016. 


\section{Appendix}

Residents in Italy aged between 18 and 74 years represent the concerned population. The parameters of this population refer to four study domains (i.e., national territory, five geographical areas, geographical regions, and municipal typologies in their effect on socioeconomic and demographic characteristics).

The population has been partitioned into four strata: age, gender, macro-area (Nielsen) of residence, and qualification. All the strata's parameters are conform to ISTAT's categories (the National Institute for Statistics).

The surveyed sample has been derived from a panel of 60,000 individuals-components have been recruited by means of online and phone sourcing techniques-and selected through stratified random sampling. Finally, a post-stratification survey weighting has been adopted.

$$
\text { (Tables } 6-14)
$$

Table 6. Distal explanatory variables (number and \% of respondents).

\begin{tabular}{|c|c|c|c|}
\hline Distal variable & Value & Tot & $\%$ \\
\hline \multirow[t]{5}{*}{ Macro region } & North-West & 1,289 & $27.3 \%$ \\
\hline & North-East & 896 & $19.0 \%$ \\
\hline & Center & 919 & $19.5 \%$ \\
\hline & South & 1,079 & $22.8 \%$ \\
\hline & Islands & 543 & $11.5 \%$ \\
\hline \multirow[t]{5}{*}{ Household size } & 1 & 516 & $10.9 \%$ \\
\hline & 2 & 1,365 & $28.9 \%$ \\
\hline & 3 & 1,260 & $26.7 \%$ \\
\hline & 4 & 1,202 & $25.4 \%$ \\
\hline & $>4$ & 383 & $8.1 \%$ \\
\hline \multirow{4}{*}{$\begin{array}{l}\text { Perception of monetary } \\
\text { wealth }\end{array}$} & Feeling Poor & 306 & $6.5 \%$ \\
\hline & $\begin{array}{r}\text { Many } \\
\text { Difficulties }\end{array}$ & 677 & $14.3 \%$ \\
\hline & $\begin{array}{r}\text { Some } \\
\text { Difficulties }\end{array}$ & 1,959 & $41.5 \%$ \\
\hline & Safely & 1,784 & $37.8 \%$ \\
\hline \multirow[t]{4}{*}{ Education level } & $\begin{array}{r}\text { Primary / } \\
\text { middle school }\end{array}$ & 964 & $20.4 \%$ \\
\hline & High school & 2,551 & $54.0 \%$ \\
\hline & Master degree & 968 & $20.5 \%$ \\
\hline & PHD & 243 & $5.1 \%$ \\
\hline \multirow[t]{3}{*}{ Yearly respondents } & 2013 & 1,706 & $36.1 \%$ \\
\hline & 2014 & 1,518 & $32.1 \%$ \\
\hline & 2015 & 1,502 & $31.8 \%$ \\
\hline \multirow[t]{2}{*}{ Gender } & Male & 2,286 & $48.4 \%$ \\
\hline & Female & 2,440 & $51.6 \%$ \\
\hline \multirow[t]{3}{*}{ Age } & $18-34$ & 1,262 & $26.7 \%$ \\
\hline & $35-64$ & 2,541 & $53.8 \%$ \\
\hline & $65+$ & 923 & $19.5 \%$ \\
\hline
\end{tabular}


Table 7. "Planning/Purchasing" phase: proximal explanatory variables (number and \% of respondents).

\begin{tabular}{|c|c|c|c|}
\hline Proximal variable & Value & Tot & $\%$ \\
\hline \multirow[t]{3}{*}{ Use of shopping list } & Never & 396 & $8.4 \%$ \\
\hline & Sometimes & 1,933 & $40.9 \%$ \\
\hline & Often & 2,397 & $50.7 \%$ \\
\hline \multirow[t]{5}{*}{$\begin{array}{l}\text { Frequency of food } \\
\text { shopping }\end{array}$} & $\begin{array}{r}\text { Every } 15 \text { days or } \\
\text { more }\end{array}$ & 274 & $5.8 \%$ \\
\hline & 1 time per week & 1,456 & $30.8 \%$ \\
\hline & $2 / 3$ times per week & 1,707 & $36.1 \%$ \\
\hline & Every 2 days & 582 & $12.3 \%$ \\
\hline & Every day & 707 & $15.0 \%$ \\
\hline \multirow{6}{*}{$\begin{array}{l}\text { Weekly household food } \\
\text { expenditure }\end{array}$} & $0-50 €$ & 544 & $11.5 \%$ \\
\hline & $50-100 €$ & 2,012 & $42.6 \%$ \\
\hline & $100-200 €$ & 1,556 & $32.9 \%$ \\
\hline & $200-300 €$ & 320 & $6.8 \%$ \\
\hline & More than $300 €$ & 91 & $1.9 \%$ \\
\hline & MISSING & 203 & $4.3 \%$ \\
\hline \multirow{4}{*}{$\begin{array}{l}\text { Frequency of non- } \\
\text { seasonal products } \\
\text { purchasing }\end{array}$} & Never & 369 & $7.8 \%$ \\
\hline & Rarely & 2,121 & $44.9 \%$ \\
\hline & Sometimes & 1,941 & $41.1 \%$ \\
\hline & Often & 295 & $6.2 \%$ \\
\hline \multirow{4}{*}{$\begin{array}{l}\text { Frequency of non-local } \\
\text { food purchasing }\end{array}$} & Never & 351 & $7.4 \%$ \\
\hline & Rarely & 1,954 & $41.4 \%$ \\
\hline & Sometimes & 2,081 & $44.0 \%$ \\
\hline & Often & 340 & $7.2 \%$ \\
\hline \multirow{2}{*}{$\begin{array}{l}\text { Person responsible for } \\
\text { shopping }\end{array}$} & Different & 1,022 & $21.6 \%$ \\
\hline & Always the same & 3,704 & $78.4 \%$ \\
\hline \multirow{3}{*}{$\begin{array}{l}\text { Take advantage of special } \\
\text { offers }\end{array}$} & Sometimes/Never & 826 & $17.5 \%$ \\
\hline & Often & 2,107 & $44.6 \%$ \\
\hline & Always & 1,793 & $38.0 \%$ \\
\hline \multirow[t]{4}{*}{ Shopping strategy } & Low cost & 281 & $6.0 \%$ \\
\hline & Pragmatic & 3,232 & $68.4 \%$ \\
\hline & High quality & 1,113 & $23.6 \%$ \\
\hline & MISSING & 100 & $2.1 \%$ \\
\hline
\end{tabular}


Table 8. Frequency of waste per food category and year (number and \% of respondents).

\begin{tabular}{|c|c|c|c|c|c|}
\hline Food category & Year & Never & Sometimes & Often & Missing \\
\hline \multirow[t]{4}{*}{ Fresh bread } & Total & $2,895(61.3 \%)$ & $1,327(28.1 \%)$ & $284(6.0 \%)$ & $220(4.7 \%)$ \\
\hline & 2013 & $1,050(61.6 \%)$ & $469(27.5 \%)$ & $76(4.4 \%)$ & $111(6.5 \%)$ \\
\hline & 2014 & $976(64.3 \%)$ & $387(25.5 \%)$ & $109(7.2 \%)$ & $46(3.0 \%)$ \\
\hline & 2015 & $869(57.9 \%)$ & $471(31.4 \%)$ & $99(6.6 \%)$ & $63(4.2 \%)$ \\
\hline \multirow[t]{4}{*}{ Cheese } & Total & $2,929(62.0 \%)$ & $1,502(31.8 \%)$ & $211(4.5 \%)$ & $84(1.8 \%)$ \\
\hline & 2013 & $1,102(64.6 \%)$ & $526(30.8 \%)$ & $56(3.3 \%)$ & $22(1.3 \%)$ \\
\hline & 2014 & $962(63.4 \%)$ & $445(29.3 \%)$ & $79(5.2 \%)$ & $32(2.1 \%)$ \\
\hline & 2015 & $865(57.6 \%)$ & $531(35.3 \%)$ & $76(5.1 \%)$ & $30(2.0 \%)$ \\
\hline \multirow{4}{*}{$\begin{array}{l}\text { Fruits and } \\
\text { vegetables }\end{array}$} & Total & $1,637(34.6 \%)$ & $2,680(56.7 \%)$ & $382(8.1 \%)$ & $27(0.6 \%)$ \\
\hline & 2013 & $642(37.6 \%)$ & $915(53.6 \%)$ & $142(8.3 \%)$ & $7(0.4 \%)$ \\
\hline & 2014 & $529(34.9 \%)$ & $860(56.6 \%)$ & $121(8.0 \%)$ & $8(0.5 \%)$ \\
\hline & 2015 & $466(31.0 \%)$ & $905(60.3 \%)$ & $119(7.9 \%)$ & $12(0.8 \%)$ \\
\hline \multirow[t]{4}{*}{ Milk and yoghurt } & Total & $2,967(62.8 \%)$ & $1,402(29.7 \%)$ & $240(5.1 \%)$ & $117(2.5 \%)$ \\
\hline & 2013 & $1,219(71.5 \%)$ & $384(22.5 \%)$ & $72(4.2 \%)$ & $31(1.8 \%)$ \\
\hline & 2014 & $917(60.4 \%)$ & $468(30.8 \%)$ & $96(6.3 \%)$ & $37(2.4 \%)$ \\
\hline & 2015 & $831(55.3 \%)$ & $550(36.6 \%)$ & $72(4.8 \%)$ & $49(3.3 \%)$ \\
\hline \multirow[t]{4}{*}{ Cold cuts } & Total & $3,184(67.4 \%)$ & $1,155(24.4 \%)$ & $199(4.2 \%)$ & $188(4.0 \%)$ \\
\hline & 2013 & $1,197(70.2 \%)$ & $378(22.2 \%)$ & $72(4.2 \%)$ & $59(3.5 \%)$ \\
\hline & 2014 & $1,063(70.0 \%)$ & $335(22.1 \%)$ & $64(4.2 \%)$ & $56(3.7 \%)$ \\
\hline & 2015 & $924(61.5 \%)$ & $442(29.4 \%)$ & $63(4.2 \%)$ & $73(4.9 \%)$ \\
\hline \multirow[t]{4}{*}{ Eggs } & Total & $3,391(71.8 \%)$ & $1,046(22.1 \%)$ & $185(3.9 \%)$ & $104(2.2 \%)$ \\
\hline & 2013 & $1,270(74.4 \%)$ & $336(19.7 \%)$ & $68(4.0 \%)$ & $32(1.9 \%)$ \\
\hline & 2014 & $1,093(72.0 \%)$ & $336(22.1 \%)$ & $52(3.4 \%)$ & $37(2.4 \%)$ \\
\hline & 2015 & $1,028(68.4 \%)$ & $374(24.9 \%)$ & $65(4.3 \%)$ & $35(2.3 \%)$ \\
\hline
\end{tabular}


Table 9. Partial Proportional Odds Model: drivers of fresh bread waste.

\begin{tabular}{|c|c|c|c|c|c|c|}
\hline $\begin{array}{l}\text { Phase and distal } \\
\text { variable }\end{array}$ & Category & $\begin{array}{l}\text { Reference } \\
\text { Category }\end{array}$ & Response level & OR & $95 \% \mathrm{Cl}$ & $\begin{array}{r}P \text { - } \\
\text { value }\end{array}$ \\
\hline $\begin{array}{l}\text { Planning/Purchasing } \\
\text { phase }\end{array}$ & Yes & No & Both & 2.62 & $(2.30-2.98)$ & $<.0001$ \\
\hline \multirow[t]{2}{*}{ Storing phase } & \multirow[t]{2}{*}{ Yes } & \multirow[t]{2}{*}{ No } & $\begin{array}{l}\text { Often vs. } \\
\text { Sometimes/Never }\end{array}$ & 0.80 & $(0.62-1.04)$ & 0.0886 \\
\hline & & & $\begin{array}{l}\text { Often/Sometimes } \\
\text { vs. Never }\end{array}$ & 1.15 & $(0.99-1.34)$ & 0.0610 \\
\hline Preparing phase & Yes & No & Both & 2.56 & $(2.16-3.04)$ & $<.0001$ \\
\hline Eating phase & Yes & No & Both & 1.41 & $(1.03-1.94)$ & 0.0323 \\
\hline Gender & Female & Male & Both & 0.85 & $(0.74-0.96)$ & 0.0093 \\
\hline \multirow[t]{4}{*}{ Macro region } & Center & \multirow[t]{4}{*}{ North-West } & Both & 1.35 & $(1.12-1.64)$ & 0.0016 \\
\hline & Islands & & Both & 1.18 & $(0.94-1.48)$ & 0.1498 \\
\hline & North-East & & Both & 1.04 & $(0.86-1.27)$ & 0.6917 \\
\hline & South & & Both & 1.45 & $(1.21-1.75)$ & $<.0001$ \\
\hline \multirow[t]{4}{*}{ Household size } & 2 & \multirow[t]{4}{*}{1} & Both & 1.01 & $(0.79-1.29)$ & 0.9267 \\
\hline & 3 & & Both & 1.28 & $(1.00-1.63)$ & 0.0475 \\
\hline & 4 & & Both & 1.36 & $(1.06-1.75)$ & 0.0156 \\
\hline & $>4$ & & Both & 1.38 & $(1.02-1.88)$ & 0.0380 \\
\hline \multirow{3}{*}{$\begin{array}{l}\text { Perception of } \\
\text { monetary wealth }\end{array}$} & Many difficulties & \multirow[t]{3}{*}{ Feeling poor } & Both & 0.92 & $(0.68-1.24)$ & 0.5759 \\
\hline & Some difficulties & & Both & 0.82 & $(0.62-1.09)$ & 0.1717 \\
\hline & Safely & & Both & 1.14 & $(0.86-1.51)$ & 0.3701 \\
\hline \multirow[t]{3}{*}{ Education level } & High school & \multirow{3}{*}{$\begin{array}{l}\text { Primary / } \\
\text { middle school }\end{array}$} & Both & 1.00 & $(0.84-1.2)$ & 0.9757 \\
\hline & Master degree & & Both & 1.21 & $(0.97-1.49)$ & 0.0871 \\
\hline & PHD & & Both & 1.07 & $(0.78-1.47)$ & 0.6637 \\
\hline \multirow[t]{4}{*}{ Yearly respondents } & 2014 & \multirow[t]{4}{*}{2013} & $\begin{array}{l}\text { Often vs. } \\
\text { Sometimes/Never }\end{array}$ & 1.57 & $(1.16-2.14)$ & 0.0038 \\
\hline & & & $\begin{array}{l}\text { Often/Sometimes } \\
\text { vs. Never }\end{array}$ & 0.99 & $(0.84-1.15)$ & 0.8513 \\
\hline & 2015 & & $\begin{array}{l}\text { Often vs. } \\
\text { Sometimes/Never }\end{array}$ & 1.41 & $(1.03-1.93)$ & 0.0327 \\
\hline & & & $\begin{array}{l}\text { Often/Sometimes } \\
\text { vs. Never }\end{array}$ & 1.24 & $(1.05-1.45)$ & 0.0091 \\
\hline \multirow[t]{2}{*}{ Age } & $18-34$ & \multirow[t]{2}{*}{$35-64$} & Both & 1.07 & $(0.92-1.24)$ & 0.3956 \\
\hline & $65+$ & & Both & 0.69 & $(0.57-0.84)$ & 0.0001 \\
\hline
\end{tabular}

Goodness-of-fit of the model: Chi-square statistic $=541.2, \mathrm{df}=26, \mathrm{p}$-value $<0.0001$

Bolded odds ratio parameters are statistically significant (0.05). 
Table 10. Partial Proportional Odds Model: drivers of cheese waste.

\begin{tabular}{|c|c|c|c|c|c|c|}
\hline $\begin{array}{l}\text { Phase and distal } \\
\text { variable }\end{array}$ & Category & $\begin{array}{l}\text { Reference } \\
\text { Category }\end{array}$ & Response level & OR & $95 \% \mathrm{CI}$ & $\begin{array}{r}\text { P- } \\
\text { value }\end{array}$ \\
\hline $\begin{array}{l}\text { Planning/Purchasing } \\
\text { phase }\end{array}$ & Yes & No & Both & 2.80 & $(2.46-3.18)$ & $<.0001$ \\
\hline \multirow[t]{2}{*}{ Storing phase } & \multirow[t]{2}{*}{ Yes } & \multirow[t]{2}{*}{ No } & $\begin{array}{l}\text { Often vs. } \\
\text { Sometimes/Never }\end{array}$ & 0.55 & $(0.42-0.74)$ & $<.0001$ \\
\hline & & & $\begin{array}{l}\text { Often/Sometimes } \\
\text { vs. Never }\end{array}$ & 1.54 & $(1.33-1.78)$ & $<.0001$ \\
\hline Preparing phase & Yes & No & Both & 1.86 & $(1.57-2.22)$ & $<.0001$ \\
\hline Eating phase & Yes & No & Both & 0.76 & $(0.54-1.07)$ & 0.1109 \\
\hline Gender & Female & Male & Both & 1.02 & $(0.90-1.16)$ & 0.7396 \\
\hline \multirow[t]{4}{*}{ Macro region } & Center & \multirow[t]{4}{*}{ North-West } & Both & 1.14 & $(0.95-1.37)$ & 0.1556 \\
\hline & Islands & & Both & 1.09 & $(0.87-1.36)$ & 0.4459 \\
\hline & North-East & & Both & 0.96 & $(0.80-1.16)$ & 0.6976 \\
\hline & South & & Both & 0.94 & $(0.79-1.13)$ & 0.5204 \\
\hline \multirow[t]{4}{*}{ Household size } & 2 & \multirow[t]{4}{*}{1} & Both & 0.80 & $(0.64-1.01)$ & 0.0589 \\
\hline & 3 & & Both & 1.16 & $(0.92-1.45)$ & 0.2138 \\
\hline & 4 & & Both & 1.04 & $(0.82-1.31)$ & 0.7759 \\
\hline & $>4$ & & Both & 1.16 & $(0.87-1.56)$ & 0.3178 \\
\hline \multirow{3}{*}{$\begin{array}{l}\text { Perception of } \\
\text { monetary wealth }\end{array}$} & Many difficulties & \multirow[t]{3}{*}{ Feeling poor } & Both & 1.07 & $(0.78-1.46)$ & 0.6783 \\
\hline & Some difficulties & & Both & 1.17 & $(0.88-1.56)$ & 0.2706 \\
\hline & Safely & & Both & 1.38 & $(1.03-1.84)$ & 0.0291 \\
\hline \multirow[t]{3}{*}{ Education level } & High school & \multirow{3}{*}{$\begin{array}{l}\text { Primary / } \\
\text { middle school }\end{array}$} & Both & 0.97 & $(0.82-1.16)$ & 0.7521 \\
\hline & Master degree & & Both & 1.09 & $(0.88-1.34)$ & 0.4300 \\
\hline & PHD & & Both & 1.14 & $(0.83-1.55)$ & 0.4209 \\
\hline \multirow[t]{2}{*}{ Yearly respondents } & 2014 & \multirow[t]{2}{*}{2013} & Both & 1.10 & $(0.95-1.29)$ & 0.2013 \\
\hline & 2015 & & Both & 1.34 & $(1.15-1.56)$ & 0.0002 \\
\hline \multirow[t]{2}{*}{ Age } & $18-34$ & \multirow[t]{2}{*}{$35-64$} & Both & 1.44 & $(1.24-1.66)$ & $<.0001$ \\
\hline & $65+$ & & Both & 0.73 & $(0.61-0.87)$ & 0.0007 \\
\hline
\end{tabular}

Goodness-of-fit of the model: Chi-square statistic $=524.4, \mathrm{df}=24, \mathrm{p}$-value $<0.0001$

Bolded odds ratio parameters are statistically significant $(0.05)$. 
Table 11. Partial Proportional Odds Model: drivers of fruits and vegetables waste.

\begin{tabular}{|c|c|c|c|c|c|c|}
\hline $\begin{array}{l}\text { Phase and distal } \\
\text { variable }\end{array}$ & Category & $\begin{array}{l}\text { Reference } \\
\text { Category }\end{array}$ & Response level & OR & $95 \% \mathrm{CI}$ & $\begin{array}{r}\text { P. } \\
\text { value }\end{array}$ \\
\hline $\begin{array}{l}\text { Planning/Purchasing } \\
\text { phase }\end{array}$ & Yes & No & Both & 3.19 & $(2.80-3.63)$ & $<.0001$ \\
\hline \multirow[t]{2}{*}{ Storing phase } & \multirow[t]{2}{*}{ Yes } & \multirow[t]{2}{*}{ No } & $\begin{array}{l}\text { Often vs. } \\
\text { Sometimes/Never }\end{array}$ & 0.91 & $(0.72-1.15)$ & 0.4224 \\
\hline & & & $\begin{array}{l}\text { Often/Sometimes } \\
\text { vs. Never }\end{array}$ & 2.97 & $(2.57-3.44)$ & $<.0001$ \\
\hline Preparing phase & Yes & No & Both & 1.81 & $(1.51-2.16)$ & $<.0001$ \\
\hline Eating phase & Yes & No & Both & 1.01 & $(0.74-1.39)$ & 0.9334 \\
\hline Gender & Female & Male & Both & 0.95 & $(0.84-1.07)$ & 0.3825 \\
\hline \multirow[t]{4}{*}{ Macro region } & Center & \multirow[t]{4}{*}{ North-West } & Both & 0.89 & $(0.75-1.06)$ & 0.1834 \\
\hline & Islands & & Both & 0.85 & $(0.69-1.05)$ & 0.1368 \\
\hline & North-East & & Both & 0.97 & $(0.81-1.15)$ & 0.6885 \\
\hline & South & & Both & 0.86 & $(0.72-1.02)$ & 0.0843 \\
\hline \multirow[t]{4}{*}{ Household size } & 2 & \multirow[t]{4}{*}{1} & Both & 1.02 & $(0.83-1.26)$ & 0.8613 \\
\hline & 3 & & Both & 1.08 & $(0.87-1.34)$ & 0.4765 \\
\hline & 4 & & Both & 1.14 & $(0.91-1.42)$ & 0.2574 \\
\hline & $>4$ & & Both & 1.05 & $(0.79-1.39)$ & 0.7345 \\
\hline \multirow{3}{*}{$\begin{array}{l}\text { Perception of } \\
\text { monetary wealth }\end{array}$} & Many difficulties & \multirow[t]{3}{*}{ Feeling poor } & Both & 1.00 & $(0.76-1.33)$ & 0.9763 \\
\hline & Some difficulties & & Both & 1.06 & $(0.82-1.37)$ & 0.6627 \\
\hline & Safely & & Both & 1.22 & $(0.94-1.59)$ & 0.1340 \\
\hline \multirow[t]{3}{*}{ Education level } & High school & \multirow{3}{*}{$\begin{array}{l}\text { Primary / } \\
\text { middle school }\end{array}$} & Both & 1.11 & $(0.95-1.30)$ & 0.2014 \\
\hline & Master degree & & Both & 1.27 & $(1.04-1.55)$ & 0.0204 \\
\hline & PHD & & Both & 1.42 & $(1.05-1.93)$ & 0.0221 \\
\hline \multirow[t]{2}{*}{ Yearly respondents } & 2014 & \multirow[t]{2}{*}{2013} & Both & 1.14 & $(0.99-1.32)$ & 0.0719 \\
\hline & 2015 & & Both & 1.21 & $(1.05-1.40)$ & 0.0099 \\
\hline \multirow[t]{2}{*}{ Age } & $18-34$ & \multirow[t]{2}{*}{$35-64$} & Both & 1.09 & $(0.94-1.25)$ & 0.2516 \\
\hline & $65+$ & & Both & 0.75 & $(0.64-0.89)$ & 0.0009 \\
\hline
\end{tabular}


Table 12. Partial Proportional Odds Model: drivers of milk and yoghurt waste.

\begin{tabular}{|c|c|c|c|c|c|c|}
\hline $\begin{array}{l}\text { Phase and distal } \\
\text { variable }\end{array}$ & Category & $\begin{array}{l}\text { Reference } \\
\text { Category }\end{array}$ & Response level & OR & $95 \% \mathrm{Cl}$ & $\begin{array}{r}\text { P- } \\
\text { value }\end{array}$ \\
\hline $\begin{array}{l}\text { Planning/Purchasing } \\
\text { phase }\end{array}$ & Yes & No & Both & 2.59 & $(2.27-2.94)$ & $<.0001$ \\
\hline \multirow[t]{2}{*}{ Storing phase } & \multirow[t]{2}{*}{ Yes } & \multirow[t]{2}{*}{ No } & $\begin{array}{l}\text { Often vs. } \\
\text { Sometimes/Never }\end{array}$ & 0.65 & $(0.49-0.85)$ & 0.0019 \\
\hline & & & $\begin{array}{l}\text { Often/Sometimes } \\
\text { vs. Never }\end{array}$ & 1.30 & $(1.12-1.50)$ & 0.0006 \\
\hline Preparing phase & Yes & No & Both & 1.57 & $(1.32-1.87)$ & $<.0001$ \\
\hline Eating phase & Yes & No & Both & 1.23 & $(0.89-1.69)$ & 0.2090 \\
\hline Gender & Female & Male & Both & 0.91 & $(0.80-1.03)$ & 0.1461 \\
\hline \multirow[t]{4}{*}{ Macro region } & Center & \multirow[t]{4}{*}{ North-West } & Both & 1.10 & $(0.92-1.33)$ & 0.2966 \\
\hline & Islands & & Both & 1.04 & $(0.83-1.30)$ & 0.7420 \\
\hline & North-East & & Both & 1.05 & $(0.87-1.27)$ & 0.5915 \\
\hline & South & & Both & 1.15 & $(0.96-1.38)$ & 0.1278 \\
\hline \multirow[t]{4}{*}{ Household size } & 2 & \multirow[t]{4}{*}{1} & Both & 0.87 & $(0.69-1.10)$ & 0.2425 \\
\hline & 3 & & Both & 1.17 & $(0.93-1.48)$ & 0.1899 \\
\hline & 4 & & Both & 1.27 & $(1.00-1.61)$ & 0.0545 \\
\hline & $>4$ & & Both & 1.17 & $(0.87-1.59)$ & 0.2960 \\
\hline \multirow{3}{*}{$\begin{array}{l}\text { Perception of } \\
\text { monetary wealth }\end{array}$} & Many difficulties & \multirow[t]{3}{*}{ Feeling poor } & Both & 0.99 & $(0.72-1.37)$ & 0.9446 \\
\hline & Some difficulties & & Both & 1.20 & $(0.90-1.61)$ & 0.2192 \\
\hline & Safely & & Both & 1.36 & $(1.01-1.83)$ & 0.0458 \\
\hline \multirow[t]{3}{*}{ Education level } & High school & \multirow{3}{*}{$\begin{array}{l}\text { Primary / } \\
\text { middle school }\end{array}$} & Both & 1.10 & $(0.92-1.32)$ & 0.2905 \\
\hline & Master degree & & Both & 1.29 & $(1.04-1.59)$ & 0.0213 \\
\hline & PHD & & Both & 1.47 & $(1.08-2.00)$ & 0.0154 \\
\hline \multirow[t]{4}{*}{ Yearly respondents } & 2014 & \multirow[t]{4}{*}{2013} & $\begin{array}{l}\text { Often vs. } \\
\text { Sometimes/Never }\end{array}$ & 1.58 & $(1.15-2.17)$ & 0.0044 \\
\hline & & & $\begin{array}{l}\text { Often/Sometimes } \\
\text { vs. Never }\end{array}$ & 1.76 & $(1.50-2.06)$ & $<.0001$ \\
\hline & 2015 & & $\begin{array}{l}\text { Often vs. } \\
\text { Sometimes/Never }\end{array}$ & 1.10 & $(0.79-1.54)$ & 0.5780 \\
\hline & & & $\begin{array}{l}\text { Often/Sometimes } \\
\text { vs. Never }\end{array}$ & 1.99 & $(1.70-2.33)$ & $<.0001$ \\
\hline \multirow[t]{2}{*}{ Age } & $18-34$ & \multirow[t]{2}{*}{$35-64$} & Both & 1.48 & $(1.28-1.71)$ & $<.0001$ \\
\hline & $65+$ & & Both & 0.71 & $(0.59-0.86)$ & 0.0004 \\
\hline
\end{tabular}

Goodness-of-fit of the model: Chi-square statistic $=552.2, \mathrm{df}=26, \mathrm{p}$-value $<0.0001$

Bolded odds ratio parameters are statistically significant (0.05). 
Table 13. Partial Proportional Odds Model: drivers of cold cuts waste.

\begin{tabular}{|c|c|c|c|c|c|c|}
\hline $\begin{array}{l}\text { Phase and distal } \\
\text { variable }\end{array}$ & Category & $\begin{array}{l}\text { Reference } \\
\text { Category }\end{array}$ & Response level & OR & $95 \% \mathrm{CI}$ & $\begin{array}{l}\text { P- } \\
\text { value }\end{array}$ \\
\hline $\begin{array}{l}\text { Planning/Purchasing } \\
\text { phase }\end{array}$ & Yes & No & Both & 2.81 & $(2.45-3.22)$ & $<.0001$ \\
\hline \multirow[t]{2}{*}{ Storing phase } & \multirow[t]{2}{*}{ Yes } & \multirow[t]{2}{*}{ No } & $\begin{array}{l}\text { Often vs. } \\
\text { Sometimes/Never }\end{array}$ & 0.53 & $(0.40-0.72)$ & $<.0001$ \\
\hline & & & $\begin{array}{l}\text { Often/Sometimes } \\
\text { vs. Never }\end{array}$ & 1.32 & $(1.13-1.54)$ & 0.0006 \\
\hline Preparing phase & Yes & No & Both & 2.05 & $(1.72-2.45)$ & $<.0001$ \\
\hline Eating phase & Yes & No & Both & 1.29 & $(0.92-1.81)$ & 0.1422 \\
\hline Gender & Female & Male & Both & 1.03 & $(0.90-1.18)$ & 0.6852 \\
\hline \multirow[t]{4}{*}{ Macro region } & Center & \multirow[t]{4}{*}{ North-West } & Both & 1.35 & $(1.10-1.65)$ & 0.0034 \\
\hline & Islands & & Both & 1.92 & $(1.53-2.42)$ & $<.0001$ \\
\hline & North-East & & Both & 0.96 & $(0.78-1.18)$ & 0.6697 \\
\hline & South & & Both & 1.47 & $(1.21-1.78)$ & 0.0001 \\
\hline \multirow[t]{8}{*}{ Household size } & \multirow[t]{2}{*}{2} & \multirow[t]{8}{*}{1} & $\begin{array}{l}\text { Often vs. } \\
\text { Sometimes/Never }\end{array}$ & 0.60 & $(0.35-1.03)$ & 0.0632 \\
\hline & & & $\begin{array}{l}\text { Often/Sometimes } \\
\text { vs. Never }\end{array}$ & 0.98 & $(0.75-1.27)$ & 0.8779 \\
\hline & \multirow[t]{2}{*}{3} & & $\begin{array}{l}\text { Often vs. } \\
\text { Sometimes/Never }\end{array}$ & 1.05 & $(0.64-1.73)$ & 0.8553 \\
\hline & & & $\begin{array}{l}\text { Often/Sometimes } \\
\text { vs. Never }\end{array}$ & 1.29 & $(1.00-1.68)$ & 0.0546 \\
\hline & \multirow[t]{2}{*}{4} & & $\begin{array}{l}\text { Often vs. } \\
\text { Sometimes/Never }\end{array}$ & 1.00 & $(0.61-1.66)$ & 0.9954 \\
\hline & & & $\begin{array}{l}\text { Often/Sometimes } \\
\text { vs. Never }\end{array}$ & 1.43 & $(1.10-1.87)$ & 0.0081 \\
\hline & \multirow[t]{2}{*}{$>4$} & & $\begin{array}{l}\text { Often vs. } \\
\text { Sometimes/Never }\end{array}$ & 0.66 & $(0.32-1.35)$ & 0.2527 \\
\hline & & & $\begin{array}{l}\text { Often/Sometimes } \\
\text { vs. Never }\end{array}$ & 1.72 & $(1.25-2.38)$ & 0.0010 \\
\hline \multirow{3}{*}{$\begin{array}{l}\text { Perception of } \\
\text { monetary wealth }\end{array}$} & Many difficulties & \multirow[t]{3}{*}{ Feeling poor } & Both & 1.07 & $(0.76-1.50)$ & 0.6980 \\
\hline & Some difficulties & & Both & 1.09 & $(0.80-1.48)$ & 0.5922 \\
\hline & Safely & & Both & 1.33 & $(0.98-1.82)$ & 0.0710 \\
\hline \multirow[t]{3}{*}{ Education level } & High school & \multirow{3}{*}{$\begin{array}{l}\text { Primary / } \\
\text { middle school }\end{array}$} & Both & 0.87 & $(0.73-1.05)$ & 0.1562 \\
\hline & Master degree & & Both & 1.06 & $(0.85-1.32)$ & 0.6242 \\
\hline & PHD & & Both & 1.07 & $(0.77-1.49)$ & 0.6744 \\
\hline \multirow[t]{2}{*}{ Yearly respondents } & 2014 & \multirow[t]{2}{*}{2013} & Both & 1.03 & $(0.87-1.21)$ & 0.7317 \\
\hline & 2015 & & Both & 1.43 & $(1.22-1.68)$ & $<.0001$ \\
\hline \multirow[t]{2}{*}{ Age } & $18-34$ & \multirow[t]{2}{*}{$35-64$} & Both & 1.18 & $(1.01-1.38)$ & 0.0346 \\
\hline & $65+$ & & Both & 0.78 & $(0.64-0.95)$ & 0.0125 \\
\hline
\end{tabular}

Goodness-of-fit of the model: Chi-square statistic $=534.5, \mathrm{df}=28, \mathrm{p}$-value $<0.0001$

Bolded odds ratio parameters are statistically significant $(0.05)$. 
Table 14. Partial Proportional Odds Model: drivers of eggs waste.

\begin{tabular}{|c|c|c|c|c|c|c|}
\hline $\begin{array}{l}\text { Phase and distal } \\
\text { variable }\end{array}$ & Category & $\begin{array}{l}\text { Reference } \\
\text { Category }\end{array}$ & Response level & OR & $95 \% \mathrm{CI}$ & $\begin{array}{r}\text { P- } \\
\text { value }\end{array}$ \\
\hline $\begin{array}{l}\text { Planning/Purchasing } \\
\text { phase }\end{array}$ & Yes & No & Both & 2.92 & $(2.55-3.36)$ & $<.0001$ \\
\hline \multirow[t]{2}{*}{ Storing phase } & \multirow[t]{2}{*}{ Yes } & \multirow[t]{2}{*}{ No } & $\begin{array}{l}\text { Often vs. } \\
\text { Sometimes/Never }\end{array}$ & 0.53 & $(0.39-0.72)$ & $<.0001$ \\
\hline & & & $\begin{array}{l}\text { Often/Sometimes } \\
\text { vs. Never }\end{array}$ & 1.02 & $(0.87-1.19)$ & 0.8437 \\
\hline Preparing phase & Yes & No & Both & 1.47 & $(1.22-1.77)$ & $<.0001$ \\
\hline Eating phase & Yes & No & Both & 1.11 & $(0.78-1.56)$ & 0.5677 \\
\hline Gender & Female & Male & Both & 0.86 & $(0.75-0.99)$ & 0.0360 \\
\hline \multirow[t]{4}{*}{ Macro region } & Center & \multirow[t]{4}{*}{ North-West } & Both & 1.01 & $(0.83-1.24)$ & 0.9176 \\
\hline & Islands & & Both & 1.06 & $(0.83-1.36)$ & 0.6236 \\
\hline & North-East & & Both & 0.95 & $(0.78-1.17)$ & 0.6503 \\
\hline & South & & Both & 1.07 & $(0.88-1.30)$ & 0.4835 \\
\hline \multirow[t]{4}{*}{ Household size } & 2 & \multirow[t]{4}{*}{1} & Both & 0.67 & $(0.53-0.85)$ & 0.0009 \\
\hline & 3 & & Both & 0.76 & $(0.60-0.96)$ & 0.0217 \\
\hline & 4 & & Both & 0.63 & $(0.49-0.81)$ & 0.0003 \\
\hline & $>4$ & & Both & 0.57 & $(0.41-0.79)$ & 0.0007 \\
\hline \multirow{3}{*}{$\begin{array}{l}\text { Perception of } \\
\text { monetary wealth }\end{array}$} & Many difficulties & \multirow[t]{3}{*}{ Feeling poor } & Both & 0.87 & $(0.62-1.22)$ & 0.4089 \\
\hline & Some difficulties & & Both & 0.82 & $(0.60-1.11)$ & 0.1961 \\
\hline & Safely & & Both & 1.00 & $(0.73-1.36)$ & 0.9792 \\
\hline \multirow[t]{3}{*}{ Education level } & High school & \multirow{3}{*}{$\begin{array}{l}\text { Primary / } \\
\text { middle school }\end{array}$} & Both & 0.92 & $(0.77-1.12)$ & 0.4145 \\
\hline & Master degree & & Both & 1.08 & $(0.86-1.35)$ & 0.5305 \\
\hline & PHD & & Both & 1.65 & $(1.20-2.27)$ & 0.0023 \\
\hline \multirow[t]{2}{*}{ Yearly respondents } & 2014 & \multirow[t]{2}{*}{2013} & Both & 1.11 & $(0.94-1.31)$ & 0.2078 \\
\hline & 2015 & & Both & 1.27 & $(1.07-1.50)$ & 0.0051 \\
\hline \multirow[t]{2}{*}{ Age } & $18-34$ & \multirow[t]{2}{*}{$35-64$} & Both & 1.33 & $(1.14-1.56)$ & 0.0004 \\
\hline & $65+$ & & Both & 0.71 & $(0.58-0.87)$ & 0.0010 \\
\hline
\end{tabular}

